Hydrol. Earth Syst. Sci. Discuss., 7, 5033-5078, 2010 www.hydrol-earth-syst-sci-discuss.net/7/5033/2010/ doi:10.5194/hessd-7-5033-2010

(c) Author(s) 2010. CC Attribution 3.0 License.
Hydrology and Earth System Sciences Discussions

\title{
Climate change and hydrological extremes in Belgian catchments
}

\author{
P. Baguis ${ }^{1}$, E. Roulin ${ }^{1}$, P. Willems ${ }^{2}$, and V. Ntegeka ${ }^{2}$
}

${ }^{1}$ Department of Meteorological Research and Development, Royal Meteorological Institute of Belgium, Avenue Circulaire 3, 1180 Brussels, Belgium

${ }^{2}$ Faculty of Engineering, Katholieke Universiteit Leuven, Kasteelpark Arenberg 40, 3001

Leuven, Belgium

Received: 7 July 2010 - Accepted: 23 July 2010 - Published: 30 July 2010

Correspondence to: P. Baguis (pierre.baguis@oma.be)

Published by Copernicus Publications on behalf of the European Geosciences Union. 


\section{Abstract}

In this study we focus our attention on the climate change impacts on the hydrological balance in Belgium. There are two main rivers in the country, the Scheldt and the Meuse, supplied with water almost exclusively by precipitation. With the climate change 5 projected by climate models for the end of the current century, one would expect that the hydrological regime of the rivers may be affected mainly through the changes in precipitation patterns and the increased potential evapotranspiration (PET) due to increased temperature throughout the year. We examine the hydrology of two important tributaries of the rivers Scheldt and Meuse, the Gete and the Ourthe, respectively. Our (TEME hydrological mi change data from the European PRUDENCE project. Two emission scenarios are considered, the SRES A2 and B2 scenarios, and the perturbation (or delta) method is used in order to assess the climate change signal at monthly time scale and provide appropriate input time series for the hydrological simulations. The ensemble of climate change scenarios used allows us to estimate the combined model and scenario uncertainty in the streamflow calculations, inherent to this kind of analysis. In this context, we also analyze extreme river flows using two probability distribution families, allowing us to quantify the shift of the extremes under climate change conditions.

\section{Introduction}

20 Belgium is mostly a lowland country, extending from the sea level in the northwest up to $694 \mathrm{~m}$ of altitude in the southeast (Ardennes range), with a temperate climate characterized by regular precipitations and relatively mild temperature variations throughout the year. In order to illustrate the magnitudes we would use general climate indices like the average yearly temperature and the total annual precipitation. For Koksijde in 25 the coast these are $9.4^{\circ} \mathrm{C}$ and $687 \mathrm{~mm}$, and for Botrange in the high Ardennes plateau $5.7^{\circ} \mathrm{C}$ and $1366 \mathrm{~mm}$, respectively.
HESSD

$7,5033-5078,2010$

\section{Climate change and hydrological \\ extremes in Belgian catchments}

P. Baguis et al.

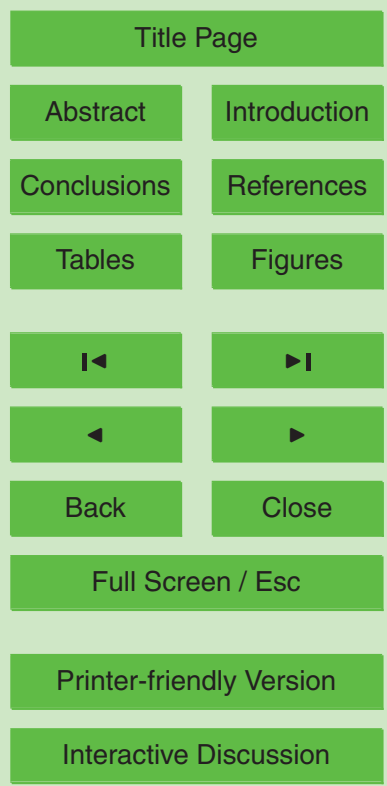


The Scheldt and the Meuse are the two main rivers of Belgium affecting many human activities in the country. Their discharge depends exclusively on precipitation, which today is rather evenly distributed and supplies them with water thoughout the year. Changes in meterological variables playing a major role in hydrology, like temperature 5 and precipitation, would have an immediate impact in the hydrological balance and consequently it would be of great importance to estimate the river discharge response to changing meteorological factors.

The warming observed during the last decades has been extensively investigated using climate models and the general consensus today is that this trend will continue 10 at least for the current century (IPCC, 2007). More specifically, according to the results of the climate model simulations, a climate shift is expected near the end of the century over Central and Northern Europe to patterns that recall the climate profile, as of today, of southern European latitudes that is warmer, dryer summers and more mild, rainier winters (Rowell and Jones, 2006; Palmer and Räisänen, 2002; Ekström et 15 al., 2005; Fowler et al., 2005). It is remarkable that the model projections are generally in agreement with the more recent observations over Europe (Brunetti et al., 2000; Marsh, 2001). Concerning Belgium in particular, the analysis of data from the meteorological stations network reveals a statistically significant increase in precipitation along the coast. This trend dissapears in the central and eastern parts of the country from the yearly total precipitation but it is still present in the winter total. On the other hand, the mean temperature has marked significant increase affecting at the same time the number of days of heat waves during summer and cold waves during winter (Brouyaux et al., 2009).

In the present study we will estimate the response to climate change of two tributaries of the rivers Scheldt and Meuse, namely of the Gete at Halen (Scheldt) and the Ourthe at Angleur (Meuse). To this end we will use data from climate models in order to produce the appropriate input for the hydrological model which is in the basis of this work. The present-day General Circulation Models (GCMs) are able to reproduce in a satisfactory way most features of Earth's climate at global and continental scales (Ran-

\section{HESSD}

$7,5033-5078,2010$

\section{Climate change and hydrological \\ extremes in Belgian catchments}

P. Baguis et al.

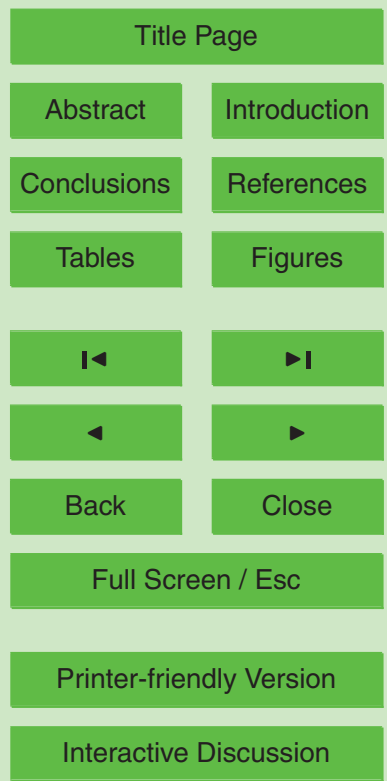


dall et al., 2008). However, the model errors are still significant especially at smaller scales where a GCM cannot resolve sub-grid processes involved in the hydrological response of a catchment. Such difficulties may lead to underestimations of the extreme events.

5 One of the possible solutions to this problem is to downscale a GCM by nesting inside it a high resolution Regional Climate Model (RCM), which will run in a more limited area with boundary conditions provided by the "surrounding" GCM. In this way a coherent, from a physical point of view, simulation is obtained and eventual nonlinear phenomena are adequately taken into account. The RCM resolution may have a 10 more or less important effect on the impact studies of hydrological extremes, depending mainly on the spatial scale and the orography (Dankers et al., 2009).

The European project PRUDENCE (Christensen et al., 2007) is based precisely on this methodology of dynamical GCM downscaling and a large number of simulations of that kind has been performed in this context. Preliminary studies using the data produced by the research teams of PRUDENCE to assess climate changes over central Belgium (Baguis et al., 2010) revealed shifts in precipitation, temperature and PET expected near the end of the current century. The derived climate scenarios were further processed by Ntegeka (2010) to tailor three climate change scenarios (high, mean and low) for hydrological impact assessment. In this latter study the three prescribed scenarios are used in order to perturb the wet-day frequency, the wet-day quantiles of precipitation intensity and PET. In the present work we use precipitation, temperature and PET perturbations, according to the deviation between the scenario and control simulations. This is a common way to deal with climate change while avoiding direct use of the biased model output. The ensemble of PRUDENCE scenarios is considered and the method is applied over a larger domain including the Meuse and the Scheldt basins in Belgium and France. We present here results obtained for two sub-catchments.

There are many sources of uncertainty in the modeling of hydrological impacts of climate change (Kay et al., 2009). The data from the PRUDENCE database allow us
HESSD

$7,5033-5078,2010$

\section{Climate change and hydrological \\ extremes in Belgian catchments}

P. Baguis et al.

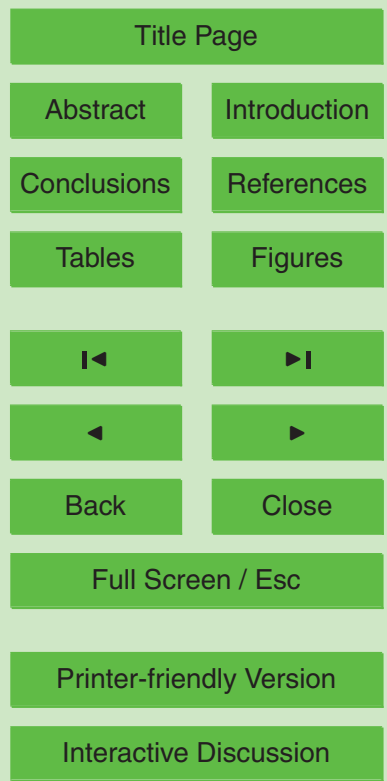


to provide a first estimation of two of them: the RCM model structure and the choice of the emission scenario. Although such estimations could never reveal the real dimensions of the problem, they are certainly useful as tools to explore the information that is available today. In our case, this will be done by using the ensemble of PRU5 DENCE RCM simulations, incorporating both model and SRES scenario uncertainty, in order to produce an ensemble of hydrological simulations on which any subsequent calculations related to climate change will be based.

We will start our analysis by presenting the hydrological setup which this work is based on (Sect. 2). This comprises a brief description of the hydrological model, 10 the techniques to process data from observations and climate model simulations, and the method adopted here to calculate the potential evapotranspiration. In Sect. 3 we present a series of results concerning river discharge. In particular, after a comparison of the hydrological model results with the observations, we proceed to the study of the climate change effect on the mean streamflow, the exceedance frequencies of certain thresholds defining low and high flows, and on extreme streamflow using two probability distributions. These results are summarized and discussed in Sect. 4.

\section{Hydrological setup}

\subsection{Study area}

We present results obtained for two contrasted catchments, the Gete and the Ourthe situated in the main two river basins in Belgium, respectively those of the Scheldt and of the Meuse (Fig. 2 and Table 1). However, results have been also obtained over the entire Scheldt basin, the Meuse basin in Belgium and upstream in France and a number of other sub-basins as well. These results are not shown here but lead to conclusions similar to the ones drawn in this paper.

25 The Gete is a tributary of the Demer, an important sub-catchment in the Eastern part of the River Scheldt Basin. It has been preferred to a larger sub-catchment in order to

\section{HESSD}

7, 5033-5078, 2010

\section{Climate change and hydrological \\ extremes in Belgian catchments}

P. Baguis et al.

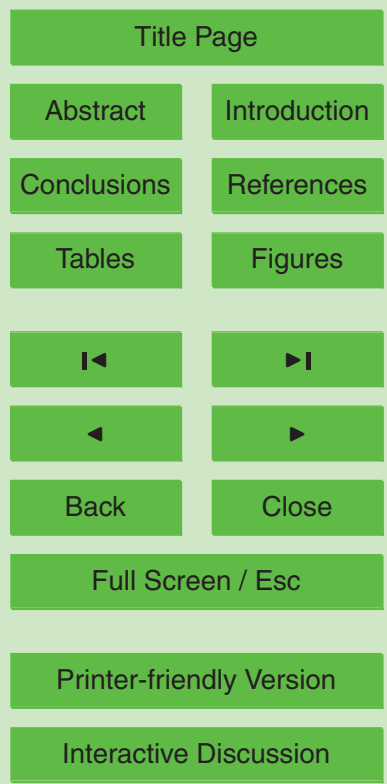


minimize the effect of flood management operated downstream. The Gete catchment is, in the southern (upstream) part, gently undulated and covered with deep loamy soils on sand, marl and locally chalk aquifers and, in the northern part fairly flat with sandy-loamy soils. The main land-cover consists in crops.

5 The Ourthe is the most important tributary of the Meuse. It is mainly situated in the Ardennes characterized by hilly topography with steep valleys and thin soils over an impermeable shale and sandstone substratum. This basin is covered almost in half by forests and then by pastures. The annual precipitation is almost twice the value over Central Belgium.

\subsection{Hydrological model}

The hydrological simulations performed for the needs of this study make use of the SCHEME (SCHEldt-MEuse) model, which is the distributed version of the IRMB hydrological model (Bultot and Dupriez, 1976). This model has been successfully applied to various catchments ranging from about 100 to $1600 \mathrm{~km}^{2}$ and representing the different 15 hydrologic conditions in Belgium (Gellens and Roulin, 1998). It has also been used to study the climate change impacts on the water cycle of the Sagana River basin in Central Kenya (Kabubi et al., 1995).

The main difference between the SCHEME and the IRMB models is that the former is intended to cover an area of about $2 \times 10^{4} \mathrm{~km}^{2}$. Also, in the SCHEME model the 20 hydrological processes are lumped within grid cells of $49 \mathrm{~km}^{2}$. This size is compatible with the use of a conceptual approach while it allows the heterogeneity of hydrologic conditions and of hydrometeorologic input data to be properly described. With this design, the SCHEME model is able to simulate a variety of basins and hydrological conditions in the river Scheldt and Meuse Basins in Belgium and upstream in France 25 (Roulin et al., 2001, 2002); it is also used in mid-range streamflow forecasts (Roulin and Vannitsem, 2005; Roulin, 2007).

The SCHEME model structure comprises 9 different land covers with a snow accumulation and melting module for each cover. The actual evapotranspiration is calcu-

\section{HESSD}

$7,5033-5078,2010$

\section{Climate change and hydrological \\ extremes in Belgian catchments}

P. Baguis et al.

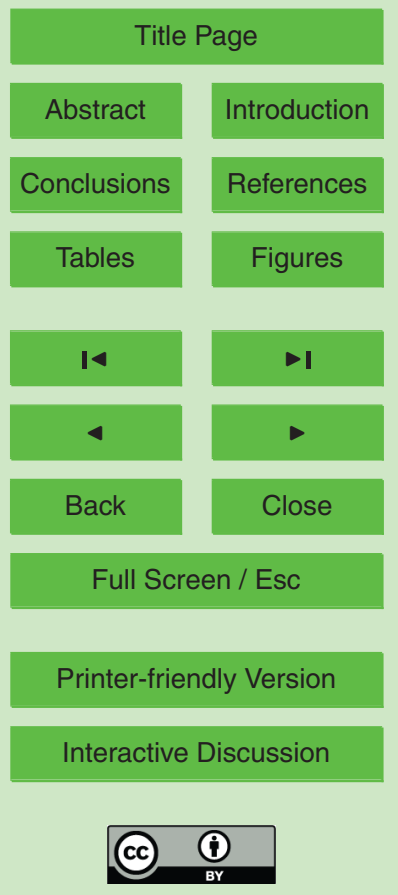


lated on the base of the water intercepted by the vegetation and the water content of two soil layers, as well as the potential evapotranspiration (PET) according to the Penman formula. Surface water is simulated with a unit hydrograph and the underground water is represented with two reservoirs. The streamflow produced on each grid cell is 5 routed to the outlet with a 1-D submodel taking into account the river network. A sketch of the SCHEME model mechanisms is presented in Fig. 1.

The parameters of the SCHEME model have been calibrated based on data from a variety of catchments in the Scheldt and the Meuse river basins from the period 1981-1988. The calibration technique combines elements from the approach in 10 Bultot and Dupriez (1976) and an automatic algorithm, the "Shuffled Complex Evolution of the University of Arizona" (SCE-UA, Duan et al., 1992, 1994), which has been proved efficient in locating globally optimal parameters of hydrological models. The objective function to optimize in this case is the daily root mean square error (RMSE). After calibration, the parameters have been regionalized over the correspond15 ing basins with the use of Artificial Neural Networks and geographic indices. Data necessary to apply such methods were provided by the CORINE Land-Cover database (http://www.eea.europa.eu/publications/COR0-landcover) and the Soil Map of the European Communities (EC, 1985).

\subsection{Data and methodology}

\subsubsection{Historical series}

For the control simulations with the SCHEME model we use observational data for the following meteorological variables: precipitation, cloud covering, temperature, wind speed, humidity, radiation and water vapor pressure. The data come from a network of meteorological station in Belgium and, for the needs of the simulations, have been interpolated so that a complete field of values be obtained at the resolution of the SCHEME model. The interpolated fields have been computed using the Thiessen polygon method for precipitation. For the other meteorological variables, we use weights

\section{HESSD}

$7,5033-5078,2010$

\section{Climate change and hydrological \\ extremes in Belgian catchments}

P. Baguis et al.

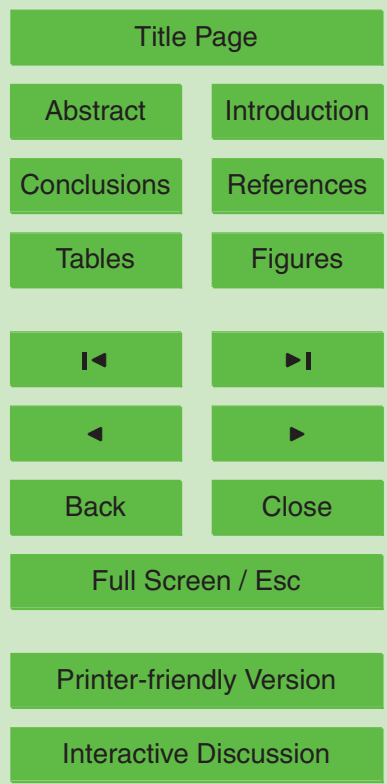


depending on the inverse of the square of the distance of each grid cell from the observation stations.

The period of availability of homogeneous and consistent data for all the necessary variables is 1966-1995. This is different from the control period of the PRUDENCE 5 project which is 1961-1990. However, due to the relative climate stability over Belgium during this period, we believe that the error introduced by this time shift is small.

Concerning now the validation of the SCHEME model, we have a complete streamflow time series over the control period only for the Ourthe river. The time series for the Gete is incomplete with seven missing years over a total of thirty. This of course will 10 affect the comparison results which should be considered having in mind the limited streamflow data availability.

Another problem with the data for the river Gete is the presence of abundant vegetation in the river bed interfering in the streamflow levels. This phenomenon is common in the small rivers of the less urbanized Flemish areas, especially in their sunlight exposed beds. The weed growth is mainly the result of the water purification programs but it raises the obvious problem for hydrologists to compute the correct river discharge. This source of error will also affect the comparison between control simulation and observations for the Gete at Halen, especially at the more extreme values of the streamflow distribution.

\subsubsection{Climate change data}

Results from climate model simulations are necessary for our study and in particular for designing and performing hydrological simulations under climate change conditions. There is today a number of Global and Regional Climate Models which are used to simulate the state of the climate system. These models run at different spatial and (see for example Hulme et al., 2002). This reflects the uncertainty inherent in the modelling procedure of an extremely complex dynamical system like the climate one.

HESSD

$7,5033-5078,2010$

\section{Climate change and hydrological \\ extremes in Belgian catchments}

P. Baguis et al.

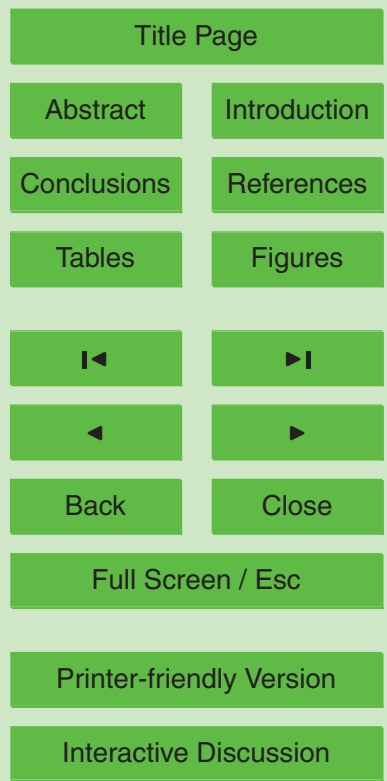


The climate models have been designed so that they can run for different periods of time, for example for the period of what we consider to be "current climate" or for a future time period in order to simulate the future climate. In this case a number of factors that could affect the climate must be taken into account. As far as anthropogenic 5 influences are concerned, the IPCC SRES scenarios for the emission of greenhouse gases (GHG) describe several possible evolutions of the human societies in the course of the current century and the ways the climate could be affected by the human activities, (IPCC, 2000). The climate change simulations, once having the form of sensitivity tests to the change of GHG concentrations (Manabe, 1983; Watts, 1980), now take into 10 account such scenarios of socioeconomic evolution and the uncertainty coming from the lack of knowledge of the future state of our society can be assessed to a certain degree.

For the needs of the present study, we process data from the database of the European project PRUDENCE (Christensen et al., 2007). The data are publicly available 15 from the web site of the project (http://prudence.dmi.dk) and are the result of many climate model simulations in which 11 RCMs are being used. The RCMs are nested within 4 different GCMs in order to provide a dynamical downscaling of the climate physics described by the GCMs, however one of the four GCMs drives 18 out of the 21 control RCM simulations. The model runs are divided into control and scenario (SRES $\mathrm{A} 2$ and B2) runs. From each RCM, we have at least one control and one SRES scenario simulation, and in some cases we have small ensembles of control and scenario simulations. The variables of interest for our analysis are the precipitation and the meteorological variables involved in the calculation of the PET (Sect. 2.3.3). The SRES A2 and B2 scenarios are derived from two different possible evolutions of the human society up to the year 2100 , leading to anthropogenic emissions of greenhouse gases that are generally higher in the A2 case. Detailed descriptions of the corresponding storylines are provided by IPCC (2000).

We process both control and scenario data from each RCM in order to estimate the climate change signal for Belgium. The corresponding calculations are based on the

\section{HESSD}

$7,5033-5078,2010$

\section{Climate change and hydrological \\ extremes in Belgian catchments}

P. Baguis et al.

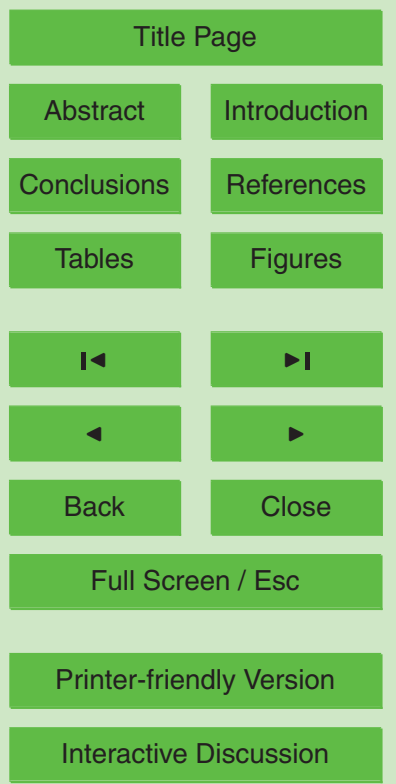


method of pertubations or delta change, which measures the deviation between the mean monthly values of each variable for the control and the scenario periods. The perturbations are expressed as differences for the temperature and as ratios for the other variables. As the PRUDENCE database provides small ensembles of simulations 5 at the control and SRES scenario levels, we calculate the perturbations by taking into account every meaningful combination of control/SRES scenario simulation. For each month, this produces a set of 41 perturbations (or possible climate change scenarios), 10 based on the SRES B2 scenario and 31 based on the SRES A2 scenario (Baguis et al., 2010). These "ensemble" perturbations are then filtered for outliers with a simple 10 statistical test. For a given month of the year and in the corresponding ensemble of perturbations, we calculate the lower and upper quartiles (25th and 75th percentiles) $Q_{1}$ and $Q_{2}$. Then the inter-quartile range is $I_{Q}=Q_{2}-Q_{1}$. The dataset extreme outliers are then those values that lie outside of the interval $\left(Q_{1}-3 /_{Q}, Q_{2}+3 /_{Q}\right)$. Such outliers are not taken into account in our analysis.

The variables that undergo perturbation for climate change are the precipitation, the temperature and the PET (after the calculations described in Sect. 2.3.3 where we use RCM control and scenario data for all the variables involved). The corresponding perturbed time series are then used as input in the SCHEME model.

The reason to not use directly $\mathrm{RCM}$ data is the presence of bias in the model output as many studies in the past have already revealed. The delta approach has as goal to remove this bias, but it succeeds to do so only under the assumption of stationary model bias. We cannot know of course if this hypothesis is true or not, but in view of the lack of such information, the delta method still remains a reasonable alternative to the direct use of the model output.

\subsubsection{Potential evapotranspiration}

There are several ways to calculate the potential evapotranspiration, ranging from the data-intensive Penman equation (Penman, 1948) to simple temperature-based formulas (Oudin et al., 2005; Kay and Davies, 2008). Previous comparisons showed that

\section{HESSD}

7, 5033-5078, 2010

\section{Climate change and hydrological \\ extremes in Belgian catchments}

P. Baguis et al.

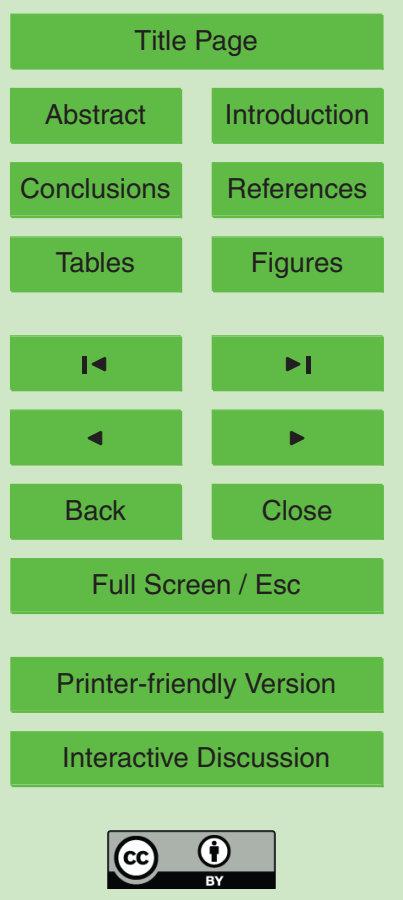


simpler PET calculations based on temperature alone, perform similarly or even better sometimes to much more complex formulations (Kannan et al., 2007). However, under climate change conditions this may be not true anymore. In fact, it has been demonstrated in Gong et al. (2006) for a large river basin in China, that the Penman equation 5 is more sensitive to changes in relative humidity than to air temperature. This implies that the PET calculations taking into account more meteorological variables than just temperature are better suited to a climate change study.

The calculation of PET in this paper is based on the Penman equation for the potential evaporation of a free water surface extending to the infinite, so that lateral heat 10 exchanges could be considered as negligible. The Penman equation is the following:

$\mathrm{E}_{0}=\frac{\delta Q_{0}^{*} / L+\gamma(\alpha+\beta w)(\epsilon-e)}{\gamma+\delta}$

where: $\mathrm{E}_{0}$ is the daily evaporation, $Q_{0}^{*}=\left(1-\alpha_{0}\right) K_{s}-L^{*}$ the total radiation balance, $K_{s}$ the total solar radiation, $L^{*}$ the net terrestrial radiation, $\alpha_{0}$ the free-water surface albedo, $L$ the vaporization latent heat of water, $\gamma=0.000662 p$ the psychrometric coefficient $(p$ is the mean atmospheric pressure), $\delta=(d \epsilon / d T)_{T}$ the saturated water vapor pressure gradient with respect to air temperature $T, \epsilon-e$ the saturation deficit ( $e$ water vapor pressure) and $w$ the mean wind speed at $2 \mathrm{~m}$. The free water surface albedo is calculated as $\alpha_{0}=(A-0.07) I_{r}^{0.4}$, where $A$ is the albedo under clear sky and $I_{r}$ the relative sunshine. The values of the parameters $\alpha$ and $\beta$ in Eq. (1) (defining the so-called wind factor) have been calculated from measurements in 11 Belgian stations and are $\alpha=0.205$ and $\beta=0.028$ (Bultot et al., 1983).

The net terrestrial radiation term $L^{*}$ can be calculated using the Monteith formula (Monteith, 1973):

$L^{*}=\sigma T^{4}\left(1-(a+b \sqrt{e})\left(1+c\left(1-I_{r}\right)^{2}\right)\right)$

25 where $\sigma$ is the Stefan-Boltzmann constant. There are again parameters $a, b$ and $c$ to be calculated and this can be done in two ways, either using mean values of the 5043

\section{HESSD}

7, 5033-5078, 2010

\section{Climate change and hydrological \\ extremes in Belgian catchments}

P. Baguis et al.

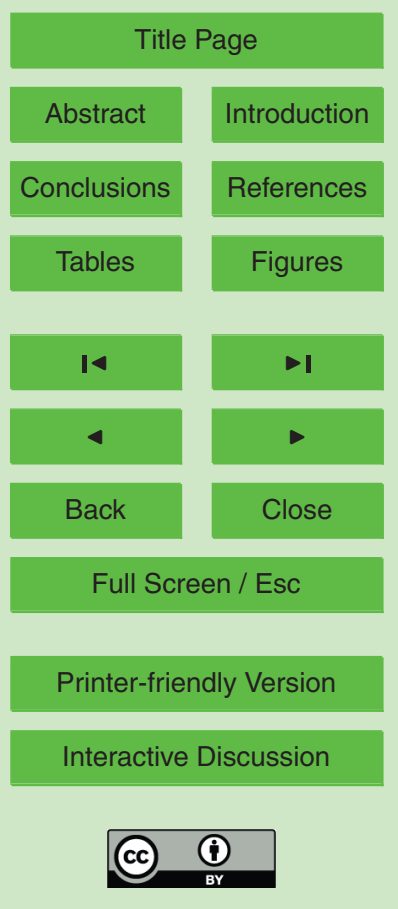


variables over $24 \mathrm{~h}$ or mean values over the daylight period of the day. This leads to two variants of the Monteith formula. The details of the parameter adjustment for Belgium can be found in Bultot et al. (1983).

There are other methods to calculate the net terrestrial radiation used in Eq. (1), like 5 applying the Idso formula for the effective clear sky emissivity (Idso, 1981) or using the $\mathrm{RCM}$ output for the net terrestrial radiation. In the present study, we use the daylight period variant of the Monteith formula (Eq. 2) with the parameter values obtained in Bultot et al. (1983).

Once the potential evaporation $\mathrm{E}_{0}$ is known, the PET of a natural cover $i$ can be 10 calculated with the formula

$$
\mathrm{PET}=f_{i} \mathrm{E}_{0}
$$

where $f_{i}$ is a coefficient given by

$$
f_{i}=\frac{\left(1-\alpha_{i}\right) K_{s}-L^{*}}{\left(1-\alpha_{0}\right) K_{s}-L^{*}}
$$

In Eq. (4), $\alpha_{i}$ is the albedo of the natural cover $i$ (Bultot et al., 1983). Validation results 15 of the PET calculation methods using RCM data for a representative station in central Belgium can be found in Baguis et al. (2010).

\section{River sreamflow results}

\subsection{Model validation}

We proceed now to a comparison between the streamflow computed by performing and the streamflow observations in the same time period for the outlets at Halen (Gete river) and Angleur (Ourthe river). Let us recall here that the measured time series we

HESSD

$7,5033-5078,2010$

\section{Climate change and hydrological \\ extremes in Belgian catchments}

P. Baguis et al.

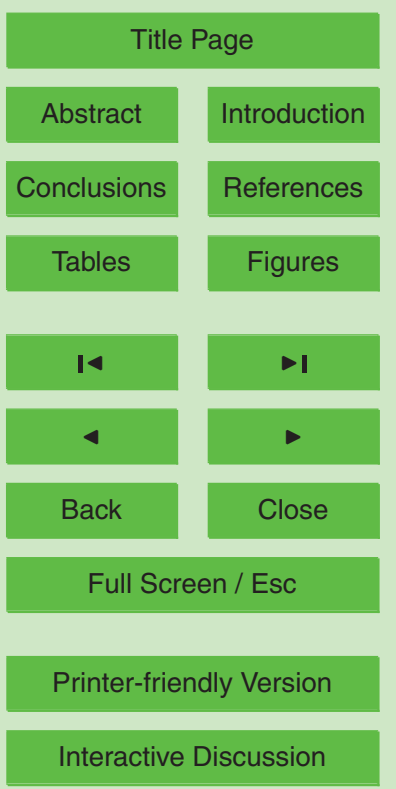


have in our disposition for the Gete are not complete in the time period of interest, so in this case the results of the comparison may be not precise.

The statistics presented here are the bias, the RMSE (normalized by the mean streamflow from the measurements), the correlation and the Nash-Sutcliffe (NS) statis5 tics of the residuals (Nash and Sutcliffe, 1970), defined as:

$$
\mathrm{NS}=1-\frac{\sum_{i=1}^{N}\left(x_{i, \mathrm{sim}}-x_{i, \mathrm{obs}}\right)^{2}}{\sum_{i=1}^{N}\left(x_{i, \mathrm{obs}}-\bar{x}_{\mathrm{obs}}\right)^{2}}
$$

where $i$ is indexing the daily time series of length $N$, the qualifiers sim and obs stand for "simulated" and "observed", respectively and $\bar{x}$ is the mean value of the variable $x$. These validation results are summarized in Table 2 . Obviously, the model performance can vary from one catchment to the other and according to the statistic considered. For example, the Gete simulation is more biased but it presents less RMSE than the Ourthe simulation. The correlation is very high in both cases. In Fig. 3 we can see the mean monthly and yearly streamflow for the two rivers considered here.

Another aspect of the SCHEME control simulations we have examined is the extreme values of the streamflow time series. We tackle this problem in two ways: (1) by calculating the absolute maximum and (2) by estimating through the fitting of a probability distribution to the sample of yearly maximal values the streamflow value with return period 100 years ( $p 99)$. These calculations are performed for both simulations and observations. For the case of the Gete at Halen we distinguish between the complete control time series and the part of the control series corresponding to the observations availability, and we process the data separately. The distribution types and fitting techniques are described in Sects. 3.3.1 and 3.3.2. The results of this comparison are presented in Table 3. The comparison between the actual maximum values in the observed and simulated times series is quite good for the case of the Ourthe. More 5045

\section{HESSD}

7, 5033-5078, 2010

\section{Climate change and hydrological \\ extremes in Belgian catchments}

P. Baguis et al.

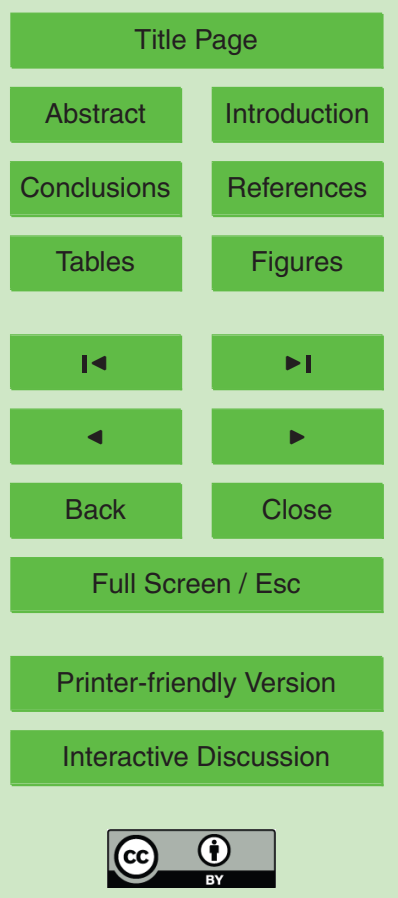


marked differences appear in the estimations of the $p 99$ streamflow values, and the result depends on the probablity distribution used, which is expected. The Gamma distribution gives larger $p 99$ values than the GEV distribution in the case of the Gete, while the opposite holds in the case of the Ourthe.

$5 \quad$ Interesting are also the $90 \%$ confidence intervals of the $p 99$ values in Table 4 . In each case there is an overlap between the intervals around the $p 99$ value calculated from the control (simulated) and the observed time series, the only exception being the case of the GEV estimations for the Gete. A more extended comparison, on the basis of estimations using probability distributions, is presented in Figs. 4 and 5 . Each

10 figure represents the streamflow estimated by probability distribution fitting to the data as a function of the return period, covering the time interval from 6 to 105 years. The $90 \%$ confidence intervals around each value are also calculated and plotted in each case. This comparison is again favorable for the case of the Ourthe at Angleur. The control and observed curves are completely contained each in the confidence intervals of the other in both Gamma and GEV estimations. The case of the Gete at Halen is less good with an overlap of the confidence intervals only in the Gamma distribution estimations. Since the observed series is not complete at Halen, we present the results based on both the complete control series and the partial control series corresponding to the observations availability. When a Gamma distribution is used the results differ only little, so only one of the two is represented (the partial control here).

\subsection{Hydrology under climate change}

Climate change can have direct and significant impacts to a hydrological system through the modifications caused to the meteorological variables that control its dynamics. Such variables are the precipitation, the temperature and the PET. Preliminary shift in these variables is expected near the end of the current century according to the PRUDENCE RCM runs. Earlier works have also demonstrated the impact of climate change to the hydrological balance in Belgium (Bultot et al., 1988; Gellens and Roulin,
HESSD

$7,5033-5078,2010$

\section{Climate change and hydrological \\ extremes in Belgian catchments}

P. Baguis et al.

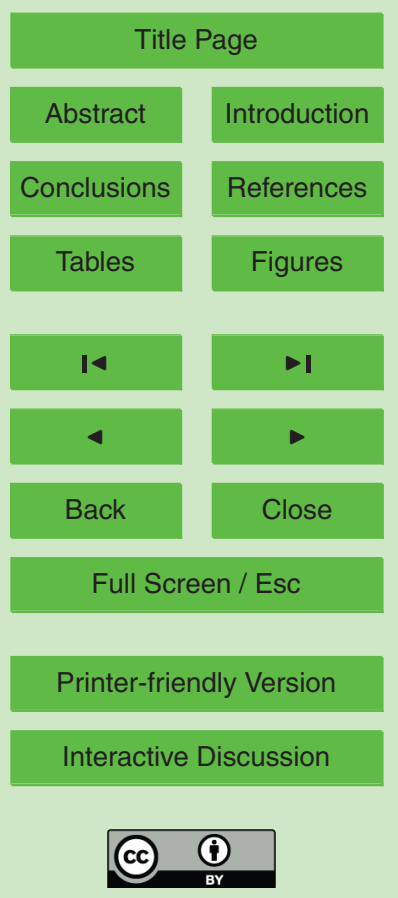


1998; Roulin et al., 2001, 2002). However, there are some limitations in these studies mostly related to the available climate change scenarios (sensitivity tests to changes of the $\mathrm{CO}_{2}$ concentration or IPCC scenarios based on very coarse resolution GCMs). Here we will investigate the impacts of the RCM-based climate change scenarios from 5 the PRUDENCE project (Sect. 2.3.2) on the hydrological balance in Belgium using the SCHEME hydrological model in the two outlets of the Gete at Halen and the Ourthe at Angleur. In particular, we will be interested in the mean streamflow profile and the more extreme behavior as well under climate change. We depict in two different ways the extreme flow events: (1) by calculating the exceedance frequencies of certain thresh10 olds and (2) by determining the change in the streamflow with a given return period (100 years) under climate change conditions. In these calculations we make use of the ensemble of the PRUDENCE climate change scenarios, discussed in Sect. 2.3.2, so that an estimation of the scenario (SRES) and model (RCM) uncertainty be possible.

\subsubsection{Mean streamflow}

15 We first calculate for each month of the year the mean streamflow for the entire scenario period (2071-2100). This calculation is performed for each member of the ensemble of hydrological simulations with the SCHEME model, based on the ensemble of climate change scenarios (perturbations). The results are graphically presented in Figs. 6 and 7. The minimum, mean and maximum curves and the corresponding 20 values included in these figures are not actual simulation curves and values, but are calculated from the monthly minimum, mean and maximum of all simulations. In this way they delimit the region in which all the simulations are contained and they indicate the mean value position for each month. However, the minimum, mean and maximum yearly values accompanying each figure have been calculated from the ensemble of

25 the actual scenario simulations. From the data in Figs. 6 and 7 we conclude that the variation margin of the mean streamflow due the SRES scenario uncertainty is larger in the $\mathrm{A} 2$ case.

\section{HESSD}

$7,5033-5078,2010$

\section{Climate change and hydrological \\ extremes in Belgian catchments}

P. Baguis et al.

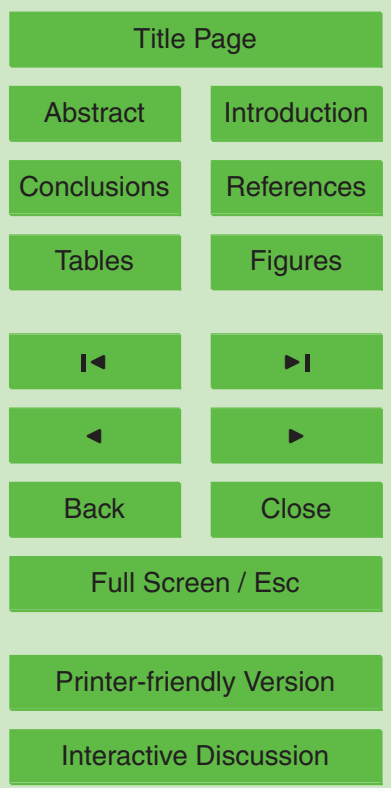


What we observe first here is that the yearly total streamflow calculated from the mean of all scenario simulations is lower than the corresponding control value. This holds for both SRES scenarios A2 and B2, and for both catchments considered here as well. Moreoever, the mean scenario curve for the streamflow (blue line) lies below 5 the control line from the middle of spring until the beginning of winter. The minimum streamflow line (in red) lies always below the control line but the maximum line (in purple) is not always above. Indeed, for a period of time ranging from 4 to 6 months during summer and autumn, even the maximum lies below the control streamflow line. For the rest of the year, the control line is contained in the region defined by the minimum 10 and maximum streamflow lines in both cases of Gete-Halen and Ourthe-Angleur. This is a first indication that, under the climate change conditions considered here, the impacts may be more severe in the lower streamflow values. We will tackle this issue in Sect. 3.2.2.

\subsubsection{Threshold exceedance frequencies}

15 The extreme streamflow behavior of a river can be studied in several ways. Here we will adopt the approach of Gellens and Roulin (1998). More precisely, we will calculate for the ensemble of the scenario simulations the exceedance frequencies of certain thresholds defining low and high flows. The thresholds are given by the 0.05 and the 0.95 percentiles calculated from the control simulation. The numbers of daily stream20 flow events below or above these values provide the low and high flow frequencies. Let us note here that the duration of the high or low flow episodes is not taken into account in this approach.

The results are shown in Figs. 8 and 9 for the low flow and in Figs. 10 and 11 for the high flow for both catchments. The minimum and maximum curves have been constructed in a way similar to the mean streamflow (Sect. 3.2.1): for each month we use the minimum and maximum value from all scenario simulations, thus delimiting the region where all the actual simulations lie. As in the case of the mean streamflow, the region corresponding to the SRES B2 scenario is more narrow than the region

\section{HESSD}

$7,5033-5078,2010$

\section{Climate change and hydrological \\ extremes in Belgian catchments}

P. Baguis et al.

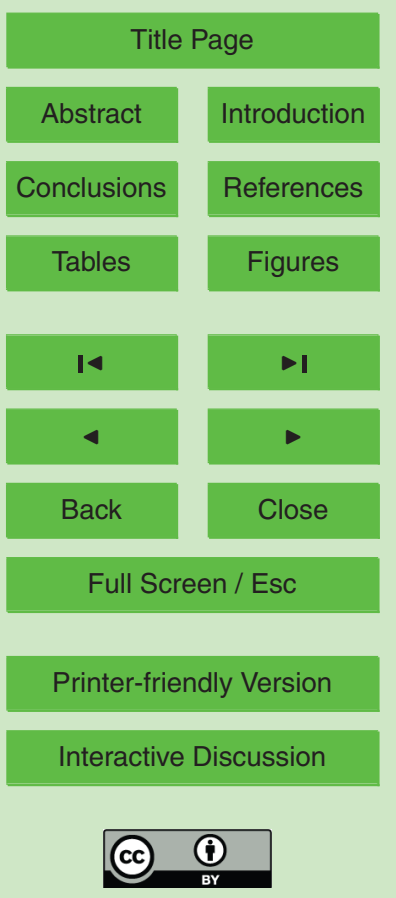


corresponding to the SRES A2 scenario, due in part to the difference in the number of simulations processed (10 based on the $B 2$ and 31 based on the $A 2$ scenario). The yearly frequencies included in these figures come from the ensemble of the actual simulations.

5 As we have pointed out in Sect. 3.2.1, even the maximum curve of the mean streamflow under climate change conditions lies below the control curve during summer and part of autumn (Figs. 6 and 7). The impact of this fact can be seen now in the low flow results (Figs. 8 and 9). For example, in the case of the Gete at Halen, the yearly control value (18.3 low flow days per year) could become any value in the intervals (32.6, 10 99.4) under the $A 2$ scenario and $(44.9,83.6)$ under the B2 scenario, with the mean of the scenario simulations being more than three times the control value. This indicates a large increase in the low flow days, concerning mostly the seasons of summer and autumn.

The climate change impacts are not equally clear in the case of the high flows frequency (Figs. 10 and 11). For example, in the case of the Ourthe at Angleur, the control value (18.3 high flow days per year) may become any value in the intervals $(12.1,28.1)$ under the A2 scenario and $(12.0,23.9)$ under the B2 scenario. Moreover, the control line is almost completely contained in the region delimited by the minumum and maximum lines. During part of the winter and spring though the curve of the mean of the scenarios lies above the control curve, so the probability of more intense high flow events in the future appears higher in this period.

In order to explain these results, one has to take into account the climate change signal over Belgium as depicted by the scenario RCM simulations used here. As Baguis et al. (2010) demonstrated, the climate change picture over Belgium can be summarized in precipitation decrease during summer and increase during winter, and large temperature and PET increase throughout the year. The combination of these factors during summer could explain the very large increase in the low flow frequency. On the other hand, during winter when high flows normally occur, the effect of the predicted increased precipitation under the climate change regime of the RCM simulations may
HESSD

$7,5033-5078,2010$

\section{Climate change and hydrological \\ extremes in Belgian catchments}

P. Baguis et al.

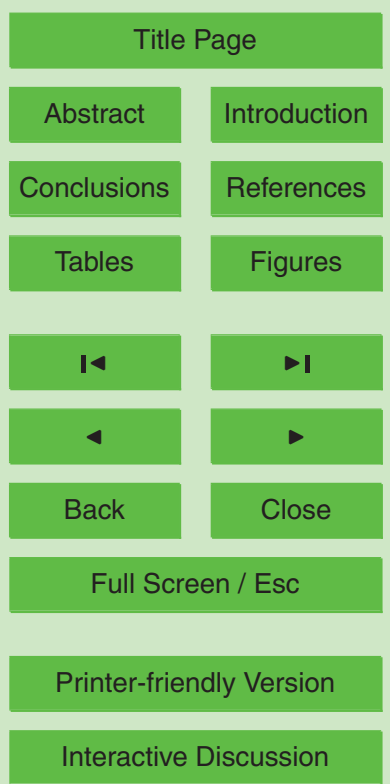




\subsection{Extreme river flows}

We proceed now to an analysis of the hydrological extremes using extreme value distributions. We will use the ensemble of RCM simulations and the two available SRES 5 scenarios, A2 and B2, in order to investigate the uncertainty in the projections concerning the future extreme hydrological events in Belgium.

In conjunction with this problem we will examine if the ensemble calculations (based on the ensemble of the scenario RCM simulations) are commutative at the extremes. By this we mean the following. For a given river outlet, we can calculate the individual streamflows by running the hydrological model for each RCM scenario and then calculate the mean of the produced streamflow ensemble. Another way to proceed would be to first calculate the mean of the RCM scenarios at the level of the hydrological model input (precipitation, PET and temperature), and then run the hydrological model just once with the mean RCM scenario. As far as the monthly mean streamflow is conthe difference in the yearly mean streamflow is very small, around $1 \%$ or less in the examples we have considered here. This is clearly shown in Fig. 12.

In the rest of this article we will also investigate this commutativity aspect in the context of hydrological extremes using two probability distribution functions. In partic$T_{0}=100$ years under precise climatic conditions. We will denote such streamflow values invariably by $p 99$. The climatic conditions of interest here are:

1. control climate for the period 1961-1990;

2. climate change according to the ensemble of:

- SRES A2 scenarios;

- SRES B2 scenarios;

HESSD

$7,5033-5078,2010$

Climate change and hydrological

extremes in Belgian catchments

P. Baguis et al.

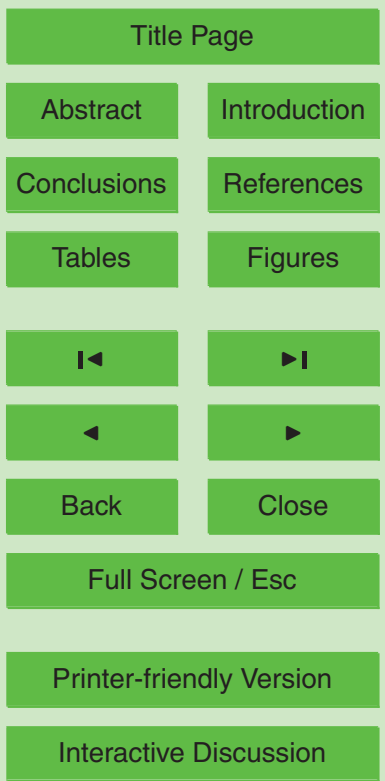


- SRES A2 + B2 scenarios;

3. climate change according to the mean scenario; all SRES scenarios (A2 and B2) are taken into account.

HESSD

$7,5033-5078,2010$

The streamflow time series used in the calculations will be determined by running 5 the SCHEME hydrological model with the prescribed climate conditions. Obviously, in case (2) an ensemble of hydrological runs is required. Then, an ensemble of $p 99$ values can be generated by fitting a probability distribution to the sample of the yearly maximum values of each run and calculating each time the variate values with return period $T_{0}$. The mean value of the $p 99$ ensemble can then be compared with the $p 99$ values obtained in cases (1) and (3). The $90 \%$ confidence intevals will finally be calculated. Especially for the case (2) where an ensemble of $p 99$ values is available, the confidence intervals will be determined by a non-parametric bootstrap method.

\subsubsection{Gamma probability distribution}

The 2-parameter Gamma distribution used in the present study is given by:

$15 f(x ; \alpha, \beta)=\frac{1}{\beta^{\alpha} \Gamma(\alpha)} x^{\alpha-1} \exp \left(-\frac{x}{\beta}\right)$

where $\Gamma$ is the Gamma function and $\alpha$ and $\beta$ are parameters that will be adjusted using a given sample of values. We have already fitted this distribution for the needs of the analysis in Sect. 3.1 to the annual maximum values of the control (from model simulation) and observed streamflow series of the catchments of Gete and Ourthe. The fitting method used here is the method of maximum likelihood.

The $p 99$ values obtained according to the climatic conditions described in Sect. 3.3 are given in the Gamma distribution column of Table 5, where some data from the Tables 3 and 4 have been included for reference. In the case of the Gete river, the $p 99$ values do not seem to change much no matter what climatic condition is considered, with a maximal change of about $7 \%$ with respect to the control value. In particular, the

\section{Climate change and hydrological \\ extremes in Belgian catchments}

P. Baguis et al.

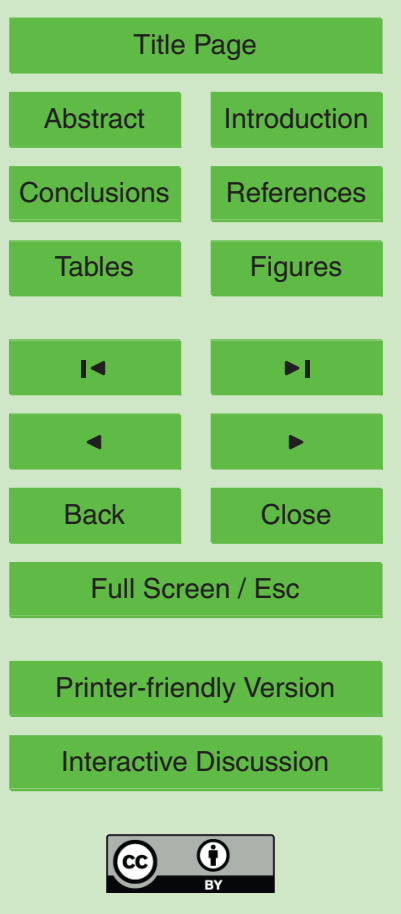


mean $p 99$ value calculated from the $\mathrm{B} 2$ simulations coincides with the control value. The same holds for the $p 99$ value from the mean scenario and the mean $p 99$ value calculated from the ensemble (A2 and B2) scenario simulations. The results indicate that under the climate change described by the PRUDENCE RCM simulations and the Gete catchment are not expected to be affected much.

The case of the Ourthe river is different though. The change in the $p 99$ value can reach up to $13 \%$ with respect to the control value when the mean $p 99$ value of the A2 simulations is taken into account. Also, when only the B2 simulations are considered, 10 the corresponding $p 99$ value is still higher than those of the control and of the mean scenario. Therefore, for the Ourthe river an increase of the extreme flow events is expected under climate change, despite the decrease in the total yearly streamflow (yearly streamflow from the mean of the scenario runs in Fig. 7).

\subsubsection{GEV probability distribution}

$f(x ; u, k, \alpha)=\frac{1}{\alpha}\left[1-k\left(\frac{x-u}{\alpha}\right)\right]^{\frac{1}{k}-1} \exp \left\{-\left[1-k\left(\frac{x-u}{\alpha}\right)\right]^{\frac{1}{k}}\right\}$

where $u, k$ and $\alpha$ are parameters that will be adjusted using a given sample of values. We already used this distribution in Sect. 3.1 for the comparison between observed and simulated streamflow series at the extremes of the distribution.

The fitting method used here is the method of probability weighted moments. The maximum likelihood method, used in the case of the Gamma distribution previously, has not be proved to be optimal in the GEV case for the available catchments since the algorithm did not converge for the obervations at Halen (Gete river). The parameter values produced by the probability weighted moments method, although different,
HESSD

$7,5033-5078,2010$

\section{Climate change and hydrological \\ extremes in Belgian catchments}

P. Baguis et al.

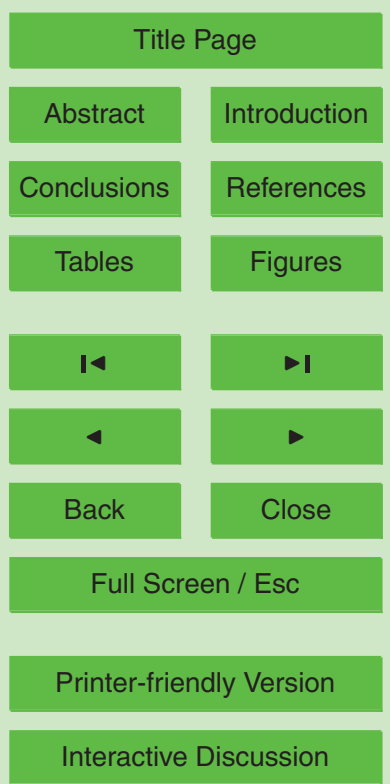


converges) for the samples used in the fitting. An example based on the control time series for both catchments is presented in Table 6. The corresponding $p 99$ values are also provided to illustrate the impact of the difference in the parameter values.

Like in the case of the Gamma distribution, we now fit a GEV distribution to the an5 nual maximum streamflow values under the climatic conditions described in Sect. 3.3. The results are given in the GEV distribution column of Table 5. For the Gete river, like in the case of the estimations based on the Gamma distribution, we observe only a small change when we compare the several $p 99$ values under the possible climate change situations with the value of the control simulation. It is also worth noting that 10 the $p 99$ values calculated with the two distributions, GEV and Gamma, are very close.

The case of the Ourthe river appears again different. The difference between the control $p 99$ value and the mean $p 99$ value computed from the ensemble of A2 simulations now exceeds $28 \%$, while the latter differs by about $13 \%$ from the $p 99$ value corresponding to the mean scenario. Overall, the estimations based on the GEV distribution 15 predict a large increase in the streamflow events with return period $T_{0}=100$ years. Also, the commutativity emerged previously in the ensemble calculations and shown clearly in Fig. 12, obviously does not hold when extreme values are concerned. This breakdown is amplified in the higher values range, as the two examples of the Gete and the Ourthe rivers illustrate.

\section{Summary and conclusions}

In this article we try to estimate the impact of climate change on the hydrological balance in Belgium. We focus in particular on two catchments, the Ourthe at Angleur and the Gete at Halen. They are two completely different catchments from a hydrological point of view, the former located in the Ardennes range and receiving abundant precipitation throught the year and the latter in lowland Flanders region (central-eastern Belgium) with significantly lower water ressources.

\section{HESSD}

$7,5033-5078,2010$

\section{Climate change and hydrological \\ extremes in Belgian catchments}

P. Baguis et al.

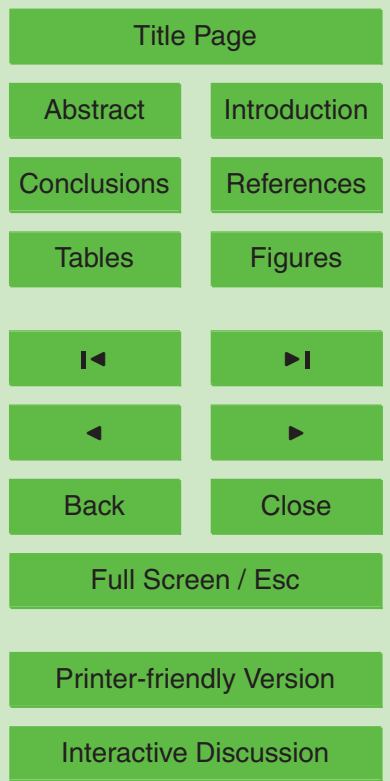


We use data from RCM simulations (PRUDENCE database) as the basis of assessing the projected climate change for the end of the current century, and the SCHEME model for our hydrological runs. The RCM data are processed in order to create the appropriate input for the SCHEME hydrological model, thus simulating streamflow se5 ries under climate change. The PRUDENCE database offers a variety of simulations that have been produced with $11 \mathrm{RCMs}$ and two SRES scenarios, A2 and B2. The ensemble of the scenario simulations allows us to proceed to estimations of uncertainty associated to the model and the emission scenario.

Our calculations concern the mean streamflow, the frequencies of low and high flow 10 events and a specific extreme streamflow situation defined here as the streamflow level with return period $T_{0}=100$ years. The mean streamflow under climate change presents a feature common in both catchments: its average over the ensemble of the scenario simulations is lower than the corresponding control value (Figs. 6 and 7) in every SRES scenario case. Moreover, looking in more detail at the seasonal and monthly level, we observe again for both catchments and SRES scenarios that for 4 to 6 months per year even the maximum values from all scenario simulations lie below the control line. This differentiates in a clear way the current and future hydrological behavior signaling a reduction of river water ressources in summer according to the RCM projections.

However, during some part of the winter, the maximum and the average of the sce20 nario simulations lie above the control line. These remarks about the mean streamflow motivate the study of the exceedance frequencies of the low and high flow thresholds. We find that the low flow events will undergo a very strong amplification under climate change which appears stronger in the case of the Ourthe river. On the other hand, the results are inconclusive in what concerns the high flow frequency: the average over the ensemble of the scenario simulations differs only by little from the control value while both average and control curves are contained in the region defined by the low and high scenario curves. A possible explanation of this behavior could be seeked in the climate change signal of the RCM simulations: higher temperature and PET throughout the year and precipitation that increases during winter and decreases dur-
HESSD

$7,5033-5078,2010$

\section{Climate change and hydrological \\ extremes in Belgian catchments}

P. Baguis et al.

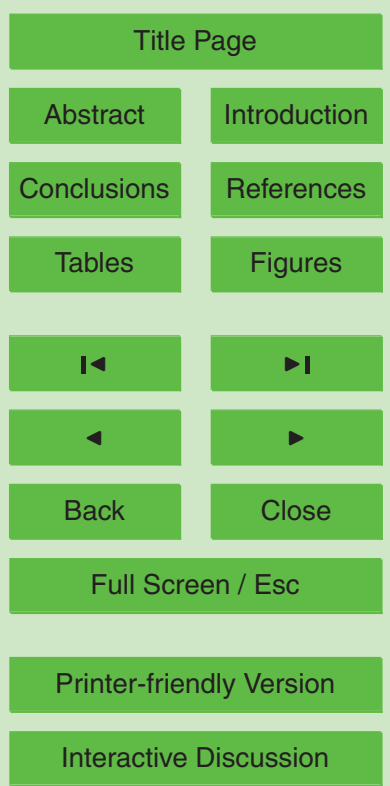


ing summer. Such results about climate change over Belgium are beyond the scope of this article and will be presented separately in a future publication. Of course we do not quantify in the present study sources of uncertainty other than the RCM model and the SRES scenario uncertainty. The fact however that these conclusions hold for both 5 catchments and SRES scenarios considered here, as illustrated by the ensemble of the simulations, builds some more confidence. Our conclusions agree also with other studies at larger (European) scale, for example Feyen and Dankers (2009).

Regarding now the extreme streamflow levels (with return period $T_{0}$ ), we should not ignore an essential difference between the confidence intervals shown in Table 5 for 10 the control and the mean scenario $p 99$ values on the one hand, and the mean of the ensemble $p 99$ values on the other hand. Indeed, the former has been obtained using the variance of the estimator while the latter is the result of a non-parametric bootstrap technique on the ensemble and thus it represents the uncertainty for the $p 99$ value due to the RCM model and the SRES scenario. Therefore, if we look at how the $p 99$ values 15 for the control and mean scenario are situated with respect to the confidence intervals of the ensembles, it becomes clear that for the case of the Gete river no significant change is expected, no matter which probability distribution or SRES ensemble is used in the calculations.

The situation is quite different in the case of the Ourthe river. Now the $p 99$ values 20 corresponding to the control and mean scenario simulations may lie inside or outside the confidence interval, depending on which SRES ensemble is taken into consideration. Thus, the B2 ensemble provides a confidence interval that contains the previous values, which means that the control and mean scenario extreme streamflows could be considered as realizations of the $\mathrm{B} 2$ simulations with $90 \%$ confidence. However, the confidence intervals associated to the $\mathrm{A} 2$ and to the $\mathrm{A} 2+\mathrm{B} 2$ ensembles have lower bounds clearly greater than the control and mean scenario $p 99$ values (Table 5), which means that these values could not be considered as randomly generated realizations of the corresponding ensembles. This property remains valid for both the Gamma and GEV probability distributions used here. It does not constitute a rigorous statistical sig-

\section{HESSD}

$7,5033-5078,2010$

\section{Climate change and hydrological \\ extremes in Belgian catchments}

P. Baguis et al.

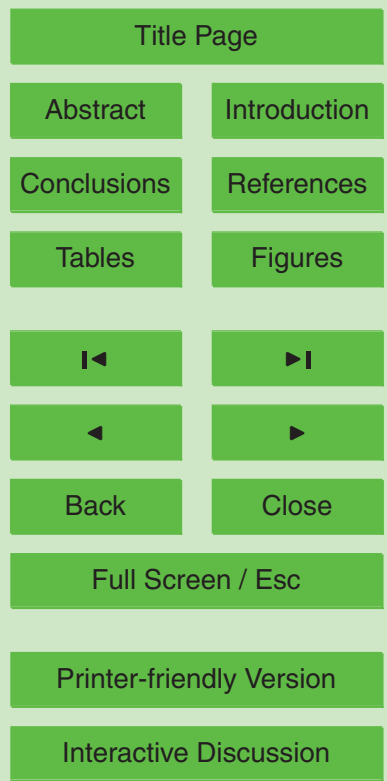


nificance test but it is sufficient to show the impact of the SRES scenario uncertainty.

Our analysis makes clear the usefulness in climate change impact studies of a good variety of climate model simulations and emission scenarios. There are obviously many other uncertainty sources one could consider (Kay et al., 2009). For example, the RCM simulations in the PRUDENCE database are driven by only 4 GCMs and from those only one drives 18 out of 21 control simulations. Therefore, there is a dominant general circulation scheme behind any analysis based on this database. At the level of the SRES scenarios, the A2 simulations are much better represented in the ensemble and consequently they also tend to dominate the average values.

Noteworthy is also the fact that although the two probability distributions Gamma and GEV used here to study the extreme streamflow give different values of the percentiles, the overall qualitative result does not change for both rivers considered. This indicates that adding more uncertainty sources in the analysis will not necessarily enlarge the uncertainty spread but instead it will help to build more confidence in the results.

15 Acknowledgements. This research was undertaken during the project "CCl-HYDR" funded by the Belgian Federal Scientific Policy under the Program "Science for a Sustainable Development" (contract SD/CP/O3B). Discharge data and useful advice were provided by Emmanuel Cornet (Hydrologische Informatie Centrum, Flemish Regional Authority), and Philippe Dierickx (Direction de la Gestion hydrologique intégrée, Walloon Regional Authority). Regional climate 20 data have been provided through the PRUDENCE data archive and are available for download from http://prudence.dmi.dk/. The authors thank Joris Vandenbergh (RMIB) for his help and discussions.

\section{References}

Baguis, P., Roulin, E., Willems, P., and Ntegeka, V.: Climate change scenarios for precipitation and potential evapotranspiration over central Belgium, Theor. Appl. Climatol., 99, 273-286, 2010. 5036, 5042, 5044, 5046, 5049

Brouyaux, F., De Backer, H., Debontridder, L., Delcloo, A., Dewitte, S., Cheymol, A., Hus, J.,

\section{HESSD}

$7,5033-5078,2010$

\section{Climate change and hydrological \\ extremes in Belgian catchments}

P. Baguis et al.

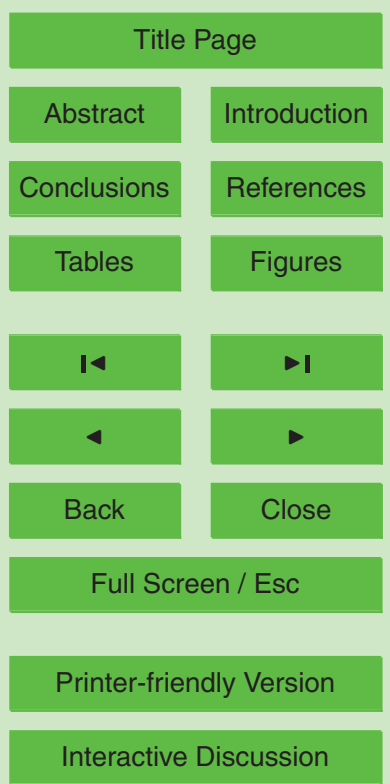


Joukoff, A., Mohymont, B., Roulin, E., Tricot, C., Van Malderen, R., Vandiepenbeeck, M., and Vannitsem, S.: Vigilance Climatique. Royal Meteorological Institute of Belgium, 2009. 5035

Brunetti, M., Buffoni, L., Maugeri, M., and Nanni, T.: Precipitation intensity trends in northern Italy, Int. J. Climatol., 20, 1017-1031, 2000. 5035

5 Bultot, F., Coppens, A., Dupriez, G.: Estimation de l'évapotranspiration potentielle en Belgique, Publications/publicaties série/serie A, $\mathrm{N}^{0} 112$, Royal Meteorological Institute of Belgium, 1983. 5043, 5044

Bultot, F., Coppens, A., Dupriez, G. L, Gellens D., and Meulenberghs, F.: Repercussions of a $\mathrm{CO}_{2}$ doubling on the water cycle and on the water balance - a case study for Belgium, J. Hydrol., 99, 319-347, 1988. 5046

Bultot, F. and Dupriez, G.: Conceptual hydrological model for an average-sized catchment area, J. Hydrol., 29, 251-292, 1976. 5038, 5039

Bultot, F., Dupriez, G., and Gellens, D.: Simulation of land use changes and impacts on the water balance - a case study for Belgium, J. Hydrol., 114, 327-348, 1990.

Christensen, J. H., Carter, T. R., Rummukainen, M., and Amanatidis, G.: Evaluating the performance and utility of regional climate models: the PRUDENCE project, Climatic Change 81, 1-6, 2007. 5036, 5041

Dankers, R. and Feyen, L.: Flood hazard in Europe in an ensemble of regional climate scenarios, J. Geophys. Res., 114, D16108, doi:10.1029/2008JD011523, 2009.

Dankers, R., Feyen, L., and Christensen, O. B.: On the benefit of high-resolution climate simulations in impact studies of hydrological extremes, Hydrol. Earth Syst. Sci. Discuss., 6, 2573-2597, doi:10.5194/hessd-6-2573-2009, 2009. 5036

Driessen, T. L. A., Hurkmans, R. T. W. L., Terink, W., Hazenberg, P., Torfs, P. J. J. F., and Uijlenhoet, R.: The hydrological response of the Ourthe catchment to climate change as modelled by the HBV model, Hydrol. Earth Syst. Sci. Discuss., 6, 7143-7178, doi:10.5194/hessd-67143-2009, 2009.

Duan, Q., Sorooshian, S., and Gupta, V. K.: Effective and efficient global optimization for conceptual rainfall-runoff models, Water Resour. Res., 28, 1015-1031, 1992. 5039

Duan, Q., Sorooshian, S. and Gupta, V. K.: Optimal use of the SCE-UA global optimisation method for calibrating watershed models, J. Hydrol., 158, 265-284, 1994. 5039

Ekström, M., Fowler, H. J., Kilsby, C. G., and Jones, P. D.: New estimates of future changes in extreme rainfall accross the UK using regional climate model integrations, 2. Future estimates and use in impact studies, J. Hydrol., 300, 234-251, 2005. 5035

\section{HESSD}

7, 5033-5078, 2010

\section{Climate change and hydrological \\ extremes in Belgian catchments}

P. Baguis et al.

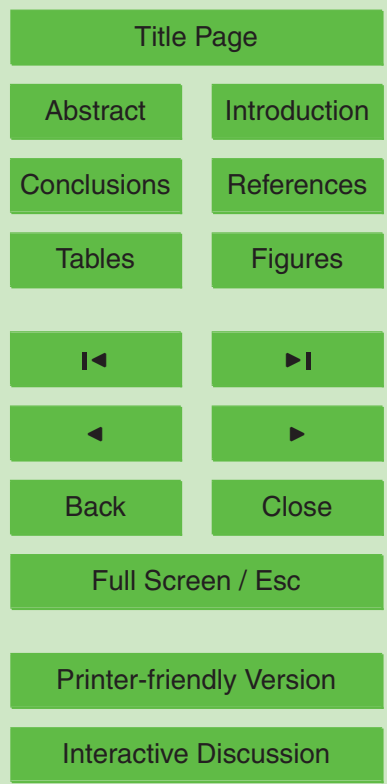


European Communities (EC): Soil Map of the European Communities at 1:1000 000, Luxembourg, 124 pp., 1985. 5039

Feyen, L. and Dankers, R.: Impact of global warming on streamflow drought in Europe, J. Geophys. Res., 114, D17116, doi:10.1029/2008JD011438, 2009. 5055

5 Fowler, H.J., Ekström, M., Kilsby, C.G. and Jones, P.D.: New estimates of future changes in extreme rainfall accross the UK using regional climate model integrations, 1. Assessment of control climate, J. Hydrol., 300, 212-233, 2005. 5035

Gellens, D. and Roulin, E.: Streamflow response of Belgian catchments to IPCC climate change scenarios, J. Hydrol., 210, 242-258, 1998. 5038, 5046, 5048

10 Gong, L., Xu, C.-Y., Chen, D., Halldin, S., and Chen, Y. D.: Sensitivity of the Penman-Monteith reference evapotranspiration to key climatic variables in the Changjiang (Yangtze River) basin, J. Hydrol., 329, 620-629, 2006. 5043

Hulme, M., Jenkins, G. J., Lu, X., Turnpenny, J. R., Mitchell, T. D., Jones, R. G., Lowe, J., Murphy, J. M., Hassel, D., Boorman, P., McDonald, R., and Hill, S.: Climate change scenarios for the United Kingdom: the UKCIP02 scientific report. Tyndall Center for Climate Change Research, School of Environmental Sciences, University of East Anglia, Norwich, UK, 2002. 5040

Idso, S. B.: A set of equations for full spectrum and 8- to $14 \mathrm{~m}$ and $10.5-$ to $12.5 \mathrm{~m}$ thermal radiation from cloudless skies, Water Resour. Res., 17, 295-304, 1981. 5044

Intergovernmental Panel on Climate Change (IPCC): Special Report for Emission Scenarios (SRES), 2000. 5041

Intergovernmental Panel on Climate Change (IPCC): Fourth assessment report: Climate change 2007 (AR4), 2007. 5035

Kabubi, J. N., Gellens, D., and Demarrée, G. R.: Response of an upland equatorial African basin to a $\mathrm{CO}_{2}$-induced climatic change, Hydrolog. Sci. J., 40(4), 453-470, 1995. 5038

Kannan, N., White, S. M., Worrall, F., and Whelan, M. J.: Sensitivity analysis and identification of the best evapotranspiration and runoff options for hydrological modelling in SWAT-2000, J. Hydrol., 332, 456-466, 2007. 5043

Kay, A. L. and Davies, H. N.: Calculating potential evaporation from climate model data: a source of uncertainty for hydrological climate change impacts, J. Hydrol., 358, 221-239, 2008. 5042

Kay, A. L., Davies, H. N., Bell, V. A., and Jones, R. G.: Comparison of uncertainty sources for climate change impacts: flood frequency in England, Climatic Change, 92, 41-63, 2009.

\section{HESSD}

7, 5033-5078, 2010

\section{Climate change and hydrological \\ extremes in Belgian catchments}

P. Baguis et al.

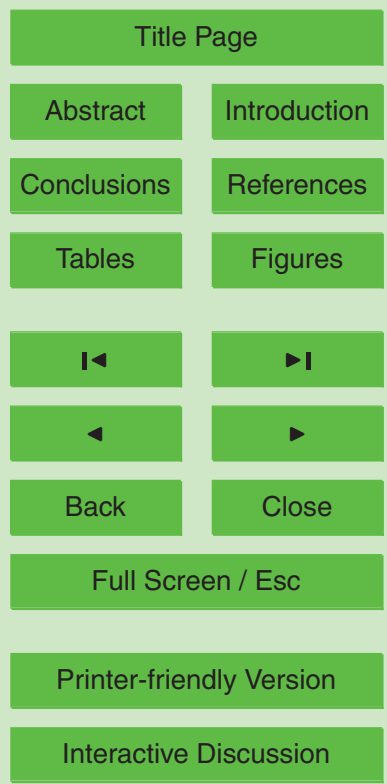


Manabe, S.: Carbon Dioxide and Climatic Change, Adv. Geophys., 25, 39-82, 1983. 5041

Marsh, T.J.: The 2000/2001 floods in the UK - a brief overview, Weather, 56, 343-345, 2001. 5035

5 Matsumoto, M. and Nishimura, T.: Mersenne Twister: A 623-dimensionally equidistributed uniform pseudorandom number generator. ACM T. Model. Comput. S.: Special Issue on Uniform Random Number Generation, 1998.

Monteith, J. L.: Principles of Environmental Physics, Contemporary Biology, Edward Arnold Ltd, London, 1973. 5043

10 Nash, J. E. and Sutcliffe, J. V.: River flow forecasting through conceptual models; part I - a discussion of principles, J. Hydrol., 10, 282-290, 1970. 5045

Ntegeka, V., Willems, P., Roulin, E., and Baguis, P.: Developing tailored climate change scenarios for hydrological impact assessments, J. Hydrol., submitted, 2010. 5036

Oudin, L., Hervieu, F., Michel, C., Perrin, C., Andreassian, V., Anctil, F., and Loumagne, C.: 15 Which potential evapotranspiration input for a lumped rainfall-runoff model? Part 2 - Towards a simple and efficient potential evapotranspiration model for rainfall-runoff modeling, J. Hydrol., 303, 290-306, 2005. 5042

Palmer, T. N. and Räisänen, J.: Quantifying the risk of extreme seasonal precipitation events in a changing climate, Nature, 415, 512-514, 2002. 5035

20 Penman, H. L.: Natural evaporation from open water, bare soil and grass, Proc. R. Soc. Lond., A193, 120-146, 1948. 5042

Randall, D. A., Wood, R. A., Bony, S., Colman, R., Fichefet, T., Fyfe, J., Kattsov, V., Pitman, A., Shukla, J., Srinivasan, J., Stouffer, R. J., Sumi, A., and Taylor, K. E.: Climate Models and Their Evaluation, in: Climate Change 2007: The Physical Science Basis. Contribution of Working Group I to the Fourth Assessment Report of the Intergovernmental Panel on Climate Change, edited by: Solomon, S., Qin, D., Manning, M., Chen, Z., Marquis, M., Averyt, K.B., Tignor, M., and Miller, H. L., Cambridge University Press, Cambridge, UK, New York, USA, 2007. 5035

Roulin, E.: Skill and relative economic value of medium-range hydrological ensemble predictions, Hydrol. Earth Syst. Sci., 11, 725-737, doi:10.5194/hess-11-725-2007, 2007. 5038

Roulin, E., Cheymol, A., Gellens, D., and Arboleda, A.: Integrated modeling of the hydrological cycle in relation to global climate change, Project report CG/34/08A, Royal Meteorological Institute of Belgium, 2001, 2002. 5038, 5047

HESSD

7, 5033-5078, 2010

\section{Climate change and hydrological \\ extremes in Belgian catchments}

P. Baguis et al.

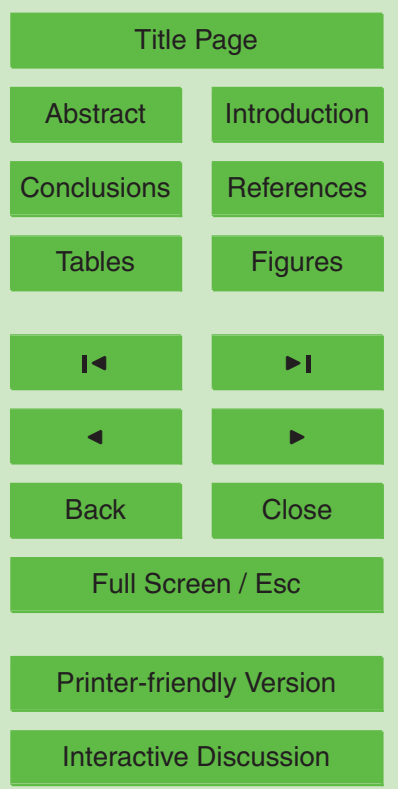


Roulin, E. and Vannitsem, S.: Skill of medium-range hydrological ensemble predictions, J. Hydrometeor., 6, 729-744, 2005. 5038

Rowell, D. P. and Jones, R. G.: Causes and uncertainty of future summer drying over Europe, Clim. Dynam., 27, 281-299, 2006. 5035

5 Sneyers, S.: On the statistical analysis of series of observations. Technical note $N^{\circ} 143$, WMO $N^{\circ} 415$, Secretariat of the World Meteorological Organization, Geneva, Switzerland, 1990.

Watts, R. G.: Climate Models and $\mathrm{CO}_{2}$ Induced Climatic Changes, Climatic Change, 2, 387408, 1980. 5041

\section{HESSD}

$7,5033-5078,2010$

Climate change and hydrological

extremes in Belgian catchments

P. Baguis et al.

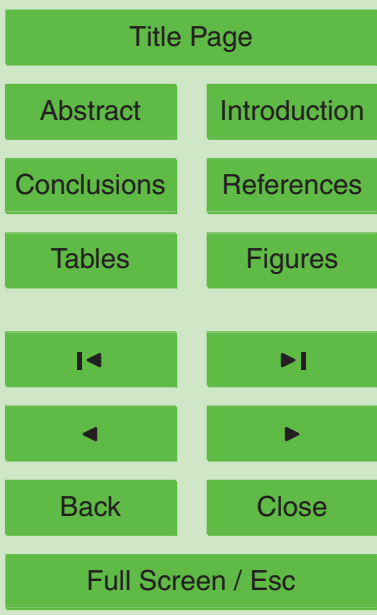

Printer-friendly Version

Interactive Discussion 


\section{HESSD}

$7,5033-5078,2010$

Climate change and hydrological

extremes in Belgian catchments

P. Baguis et al.

Table 1. Characteristics of the catchments: area, elevation range, fraction of the catchment (\%) covered by deciduous forests (De), coniferous forests (Co), pastures (Pa), crops ( $\mathrm{Cr}$ ), and urban areas (Ur) processed from CORINE land-cover database.

\begin{tabular}{llcclllll}
\hline River & Outlet & Area $\left(\mathrm{km}^{2}\right)$ & Elevation $(\mathrm{m})$ & $\mathrm{De}$ & $\mathrm{Co}$ & $\mathrm{Pa}$ & $\mathrm{Cr}$ & $\mathrm{Ur}$ \\
\hline Gete & Halen & 810 & $20-170$ & 9 & 0 & 21 & 66 & 4 \\
Ourthe & Angleur & 3627 & $60-690$ & 22 & 25 & 39 & 11 & 3 \\
\hline
\end{tabular}

Title Page

Abstract Introduction

Conclusions References

Tables

Figures

14

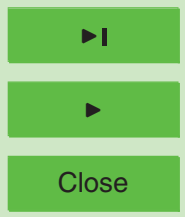

Back

Full Screen / Esc

Printer-friendly Version

Interactive Discussion 


\section{HESSD}

7, 5033-5078, 2010

Climate change and hydrological

extremes in Belgian catchments

P. Baguis et al.

Table 2. Streamflow comparison for the Ourthe and Gete rivers.

\begin{tabular}{lccccc}
\hline Catchment & Time period & Bias (\%) & RMSE (\%) & Correlation & NS Statistics \\
\hline Ourthe-Angleur & $1966-1995$ & 7.9 & 57.8 & 0.90 & 0.72 \\
Gete-Halen & $1969-1995$ & 16.4 & 45.5 & 0.89 & 0.52 \\
\hline
\end{tabular}

Title Page

Abstract

Conclusions

Tables

14

4

Back

Full Screen / Esc

Printer-friendly Version

Interactive Discussion 


\section{HESSD}

$7,5033-5078,2010$

Climate change and hydrological

extremes in Belgian catchments

P. Baguis et al.

Table 3. Extreme streamflow (p99) comparison for the Ourthe and Gete rivers (values in $\mathrm{mm} /$ day); results for the complete control series of Gete-Halen are included (last table line).

\begin{tabular}{lcccccc}
\hline Catchment & Maximum obs. & Maximum sim. & \multicolumn{2}{c}{ Gamma } & \multicolumn{2}{c}{ GEV } \\
& & & $p 99$ obs. & $p 99$ sim. & $p 99$ obs. & $p 99$ sim. \\
\hline Ourthe-Angleur & 17.0 & 17.3 & 21.2 & 18.9 & 22.1 & 19.6 \\
Gete-Halen & 2.7 & 3.8 & 3.6 & 4.3 & 2.6 & 3.7 \\
& & 3.8 & & 4.3 & & 4.2 \\
\hline
\end{tabular}

Title Page

Abstract

Conclusions

Tables

14

4

Back

Full Screen / Esc

Printer-friendly Version

Interactive Discussion 


\section{HESSD}

$7,5033-5078,2010$

Climate change and hydrological

extremes in Belgian catchments

P. Baguis et al.

Table 4. $90 \%$ confidence intervals for extreme streamflow ( $p 99)$ from observations and control simulations - Ourthe and Gete rivers (values in $\mathrm{mm} /$ day); results for the complete control series of Gete-Halen are included (last table line).

\begin{tabular}{lcccc}
\hline Catchment & \multicolumn{2}{c}{ Gamma } & \multicolumn{2}{c}{ GEV } \\
& $p 99$ obs. & $p 99$ sim. & $p 99$ obs. & $p 99$ sim. \\
\hline Ourthe-Angleur & $(18.0,25.9)$ & $(16.7,22.1)$ & $(15.6,28.7)$ & $(15.1,24.2)$ \\
Gete-Halen & $(3.1,4.2)$ & $(3.8,4.9)$ & $(2.3,2.9)$ & $(3.3,4.1)$ \\
& & $(3.8,4.9)$ & & $(3.5,4.8)$ \\
\hline
\end{tabular}

Title Page

Abstract

Conclusions

Tables

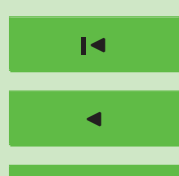

Back

Full Screen / Esc

Printer-friendly Version

Interactive Discussion 


\section{HESSD}

$7,5033-5078,2010$

\section{Climate change and hydrological \\ extremes in Belgian catchments}

Table 5. $p 99$ streamflow values and associated confidence intervals for the Ourthe and Gete rivers (values in $\mathrm{mm} /$ day) under a variety of climatic conditions. The unique $p 99$ values presented in the scenario ensemble cases are the mean values of the corresponding $p 99$ ensemble.

\begin{tabular}{lcccccccc}
\hline & \multicolumn{3}{c}{ Estimations from Gamma distribution } & \multicolumn{4}{c}{ Estimations from GEV distribution } \\
Catchment & \multicolumn{2}{c}{ Ourthe-Angleur } & \multicolumn{2}{c}{ Gete-Halen } & \multicolumn{2}{c}{ Ourthe-Angleur } & \multicolumn{2}{c}{ Gete-Halen } \\
Statistic & $p 99$ & $90 \%$ conf. & $p 99$ & $90 \%$ conf. & $p 99$ & $90 \%$ conf. & $p 99$ & $90 \%$ conf. \\
\hline Control & 18.9 & $(16.7,22.1)$ & 4.3 & $(3.8,4.9)$ & 19.6 & $(15.1,24.2)$ & 4.2 & $(3.5,4.8)$ \\
Mean scenario & 19.7 & $(17.4,23.2)$ & 4.5 & $(4.0,5.2)$ & 22.3 & $(15.3,29.3)$ & 4.0 & $(3.5,4.6)$ \\
SRES A2 ens. & 21.4 & $(20.5,22.5)$ & 4.6 & $(4.3,4.8)$ & 25.2 & $(23.8,26.7)$ & 4.4 & $(4.2,4.7)$ \\
SRES B2 ens. & 20.8 & $(18.3,24.6)$ & 4.3 & $(3.9,5.2)$ & 24.0 & $(20.7,26.7)$ & 4.2 & $(3.6,5.1)$ \\
SRES A2 + B2 ens. & 21.2 & $(20.3,22.6)$ & 4.5 & $(4.3,4.8)$ & 24.9 & $(23.5,26.3)$ & 4.4 & $(4.1,4.7)$ \\
\hline
\end{tabular}

Title Page

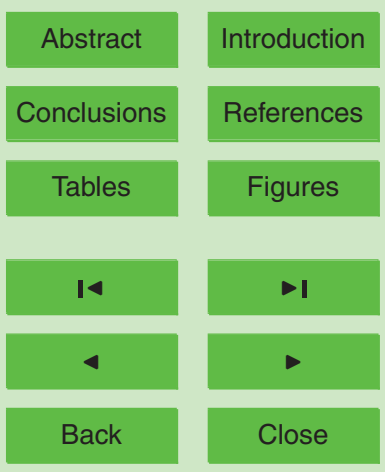

Full Screen / Esc

Printer-friendly Version

Interactive Discussion 


\section{HESSD}

$7,5033-5078,2010$

\section{Climate change and hydrological \\ extremes in Belgian catchments}

P. Baguis et al.

Table 6. Parameter values for the GEV distribution and corresponding $p 99$ values using the maximum likelihood method and the method of probability weighted moments; results based on the control simulations.

\begin{tabular}{lcccccccc}
\hline & & Maximum likelihood & & \multicolumn{3}{c}{ Probability weighted moments } \\
\hline & $u$ & $k$ & $\alpha$ & $p 99$ & $u$ & $k$ & $\alpha$ & $p 99$ \\
Ourthe-Angleur & 9.032 & $9.865 \times 10^{-2}$ & 2.689 & 19.0 & 8.971 & $9.090 \times 10^{-2}$ & 2.834 & 19.6 \\
Gete-Halen & 2.342 & 0.224 & 0.590 & 4.0 & 2.325 & 0.180 & 0.589 & 4.2 \\
\hline
\end{tabular}

Title Page

Abstract Introduction

Conclusions

References

Tables

Figures

14

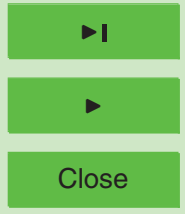

Back

Full Screen / Esc

Printer-friendly Version

Interactive Discussion 


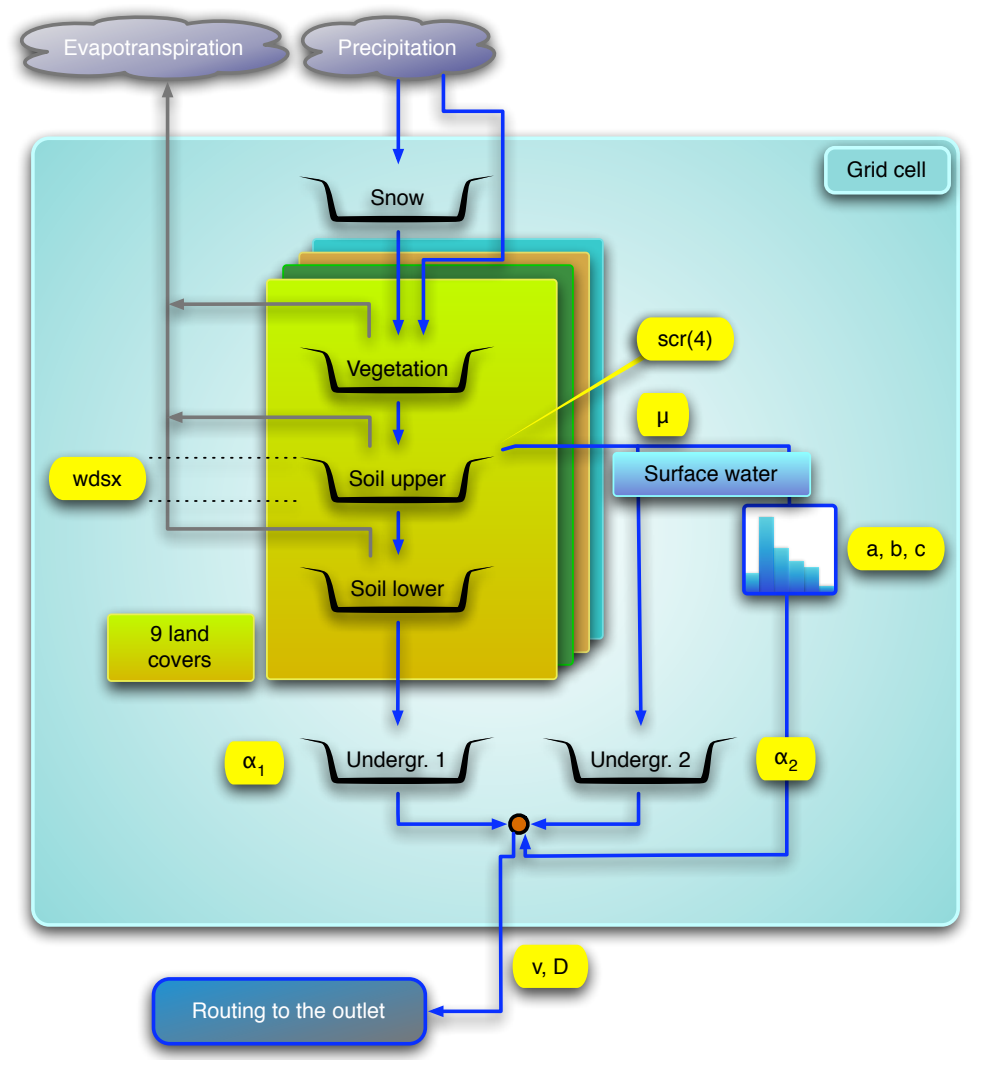

HESSD

$7,5033-5078,2010$

Climate change and hydrological

extremes in Belgian catchments

P. Baguis et al.

Fig. 1. Diagram of the SCHEME model. Model parameters: (1) wdsx, threshold value for upper soil reservoir; (2) scr(4), seasonal runoff coefficients; (3) $\mu$, redirection coefficient for surface flow; (4) a, b and c, parameters describing a unit hydrograph; (5) $\alpha_{1}$ and $\alpha_{2}$, recession coefficients of the underground reservoirs; (6) $v$ and $D$, routing module parameters.

Title Page

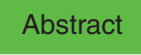

Introduction

Conclusions

References

Tables

Figures

14

4

Back

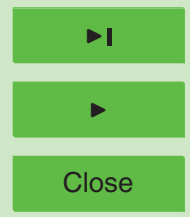

Full Screen / Esc

Printer-friendly Version

Interactive Discussion 


\section{HESSD}

$7,5033-5078,2010$

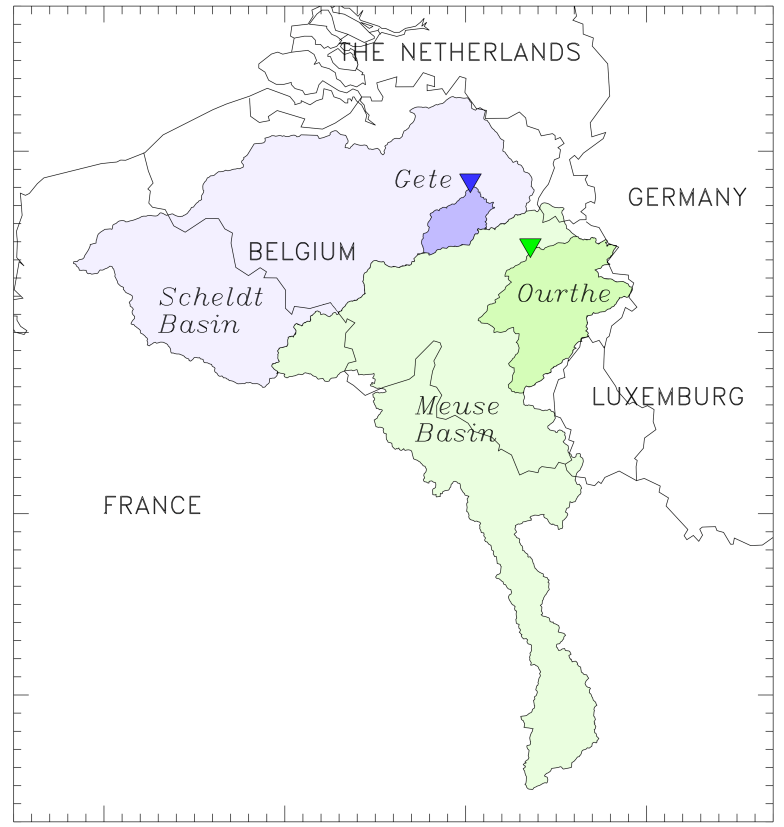

Climate change and hydrological

extremes in Belgian catchments

P. Baguis et al.

Fig. 2. Map of the Scheldt and Meuse river basins (light blue and light green, respectively) showing the two catchments of Gete and Ourthe with the corresponding outlets at Halen and Angleur (blue and green regions; outlets indicated by triangles).

Title Page

Abstract Introduction

Conclusions

References

Tables

Figures

14

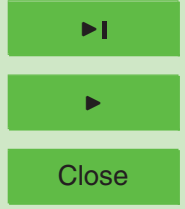

Back

Full Screen / Esc

Printer-friendly Version

Interactive Discussion 


\section{HESSD}

$7,5033-5078,2010$

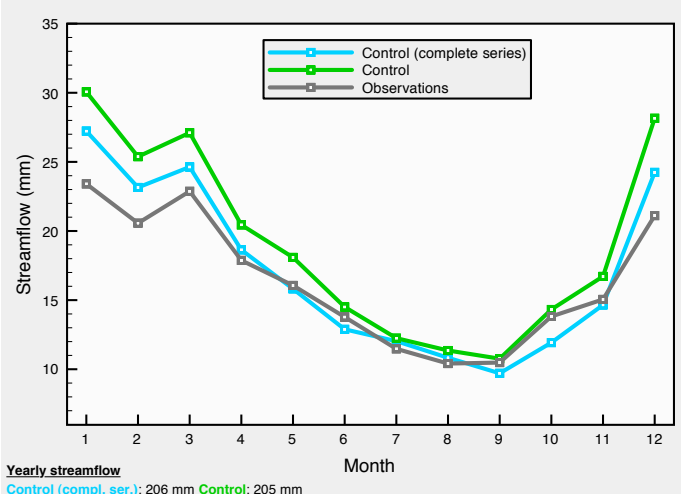

Control (compl. ser.): $206 \mathrm{~mm}$ Control: $205 \mathrm{~mm}$
Observations: $197 \mathrm{~mm}$

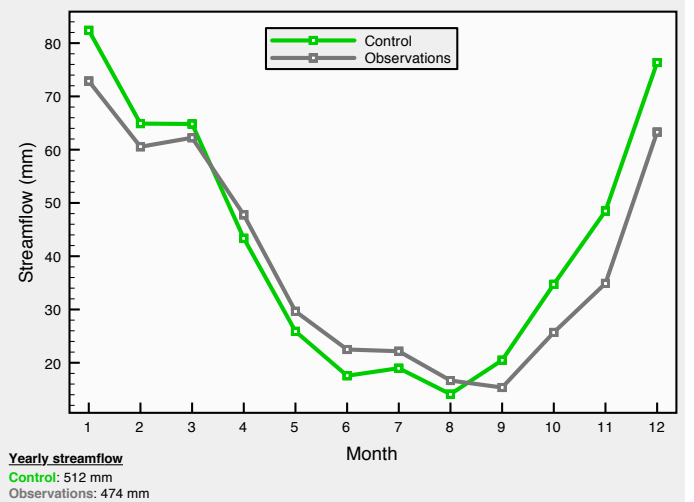

Fig. 3. Mean streamflow from observations and control simulations. Left: Gete at Halen; right: Ourthe at Angleur. In the case of the river Gete we represent two control data sets: one from the complete control simulation series and another one from the part of the control series corresponding to the years where observations for that river are available.

\section{Climate change and hydrological \\ extremes in Belgian catchments}

P. Baguis et al.

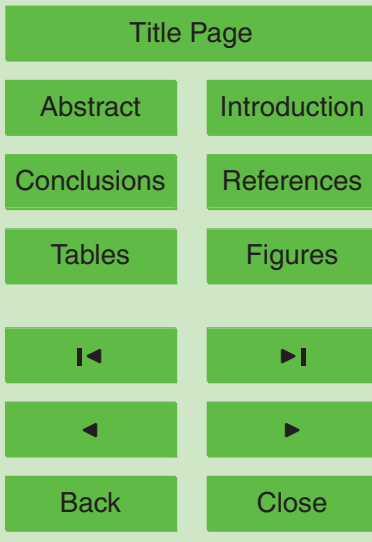

Full Screen / Esc

Printer-friendly Version

Interactive Discussion 


\section{HESSD}

$7,5033-5078,2010$
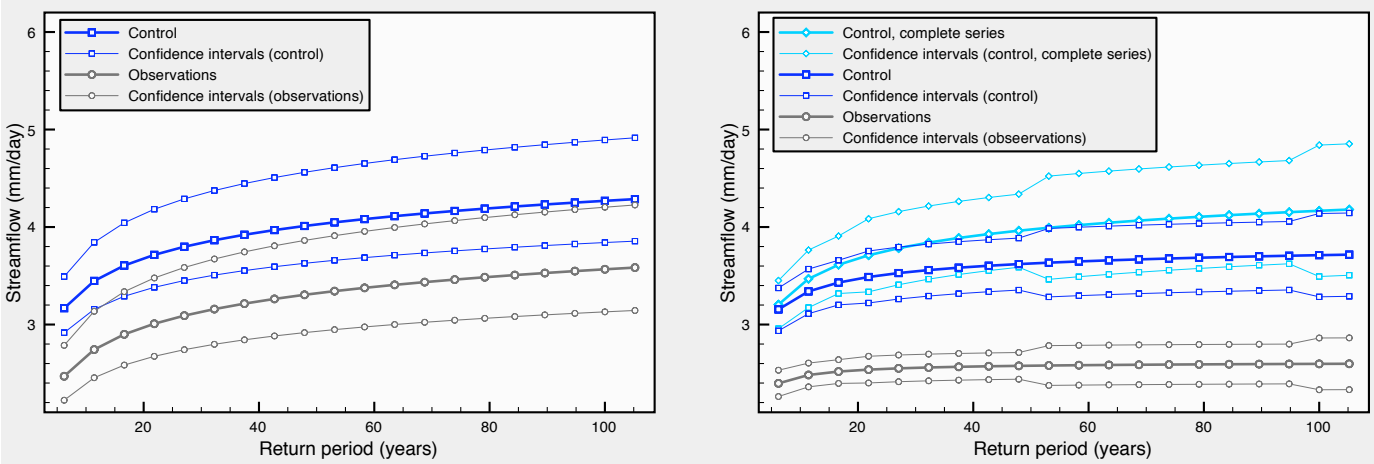

Climate change and hydrological

extremes in Belgian catchments

P. Baguis et al.

Fig. 4. Streamflow as function of the return period, based on the Gamma (left) and GEV (right) distribution estimations - Gete at Halen.

Title Page

Abstract Introduction

Conclusions

References

Tables

Figures

14

$\rightarrow$ I

4

Back

Close

Full Screen / Esc

Printer-friendly Version

Interactive Discussion 


\section{HESSD}

$7,5033-5078,2010$
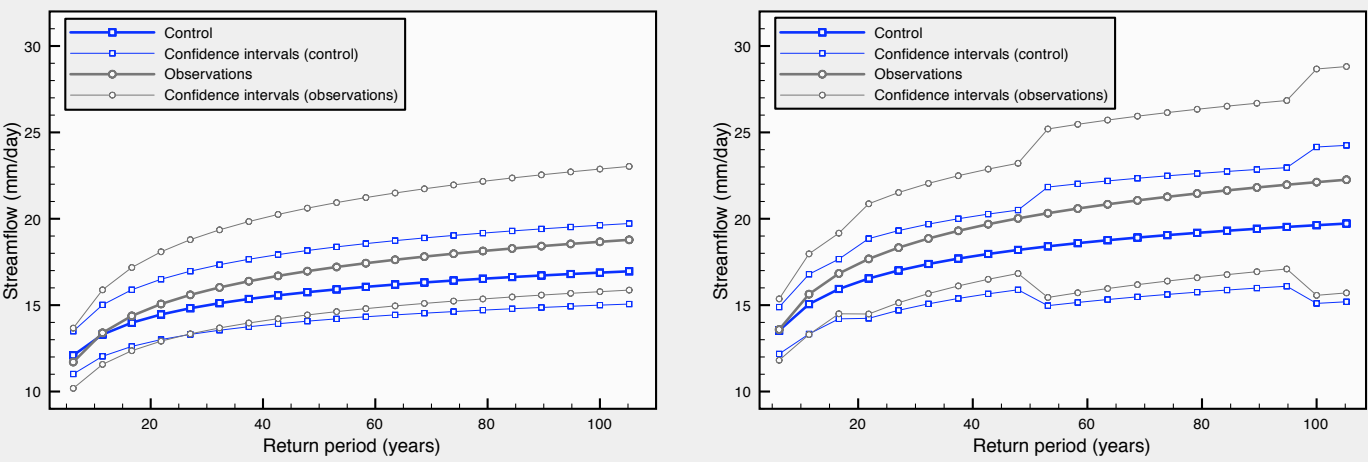

Fig. 5. Streamflow as function of the return period, based on the Gamma (left) and GEV (right) distribution estimations - Ourthe at Angleur.

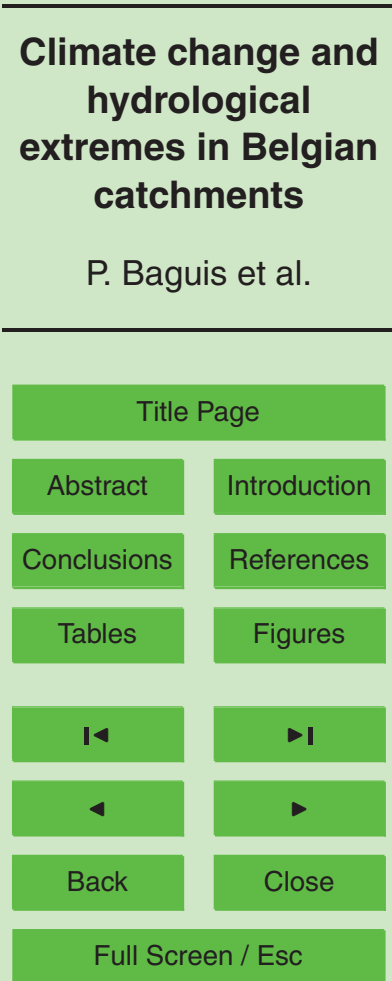

Printer-friendly Version

Interactive Discussion 


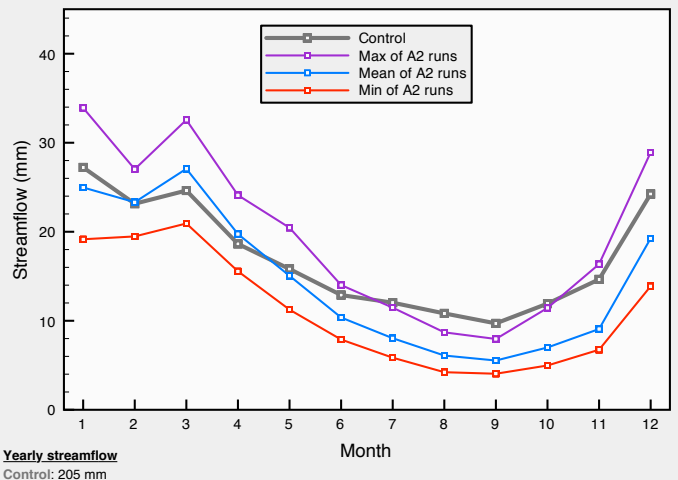

Min: $145 \mathrm{~mm}$, Mean: $176 \mathrm{~mm}$, Max: $223 \mathrm{~mm}$

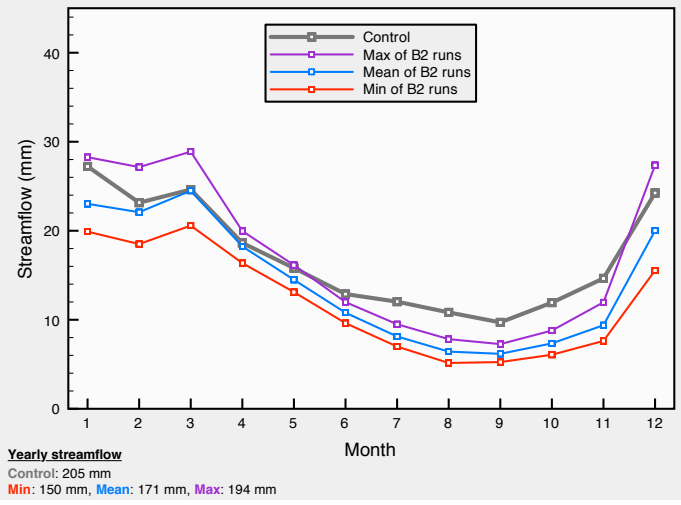

Fig. 6. Mean streamflow from control and climate change (SRES A2 and B2) hydrological simulations - Gete at Halen.

\section{HESSD}

$7,5033-5078,2010$

\section{Climate change and} hydrological

extremes in Belgian catchments

P. Baguis et al.

\section{Title Page}

\section{Abstract}

Introduction

Conclusions

References

Tables

Figures

14

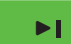

$\triangleleft$

Back

Close

\section{Full Screen / Esc}

Printer-friendly Version

Interactive Discussion 


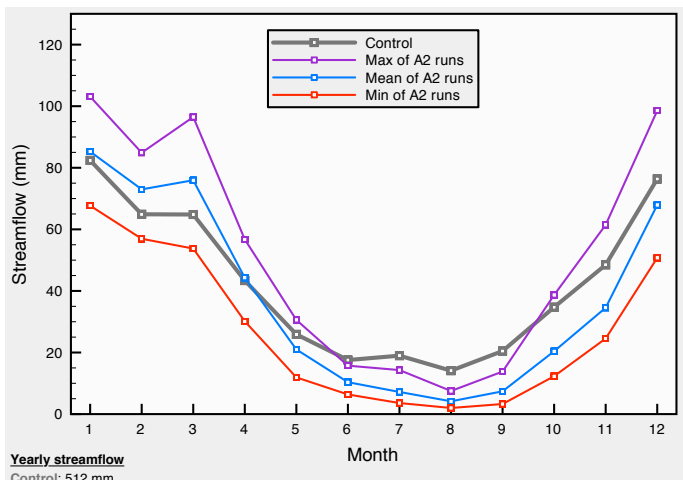

$451 \mathrm{~mm}, \operatorname{Max}: 573 \mathrm{~mm}$

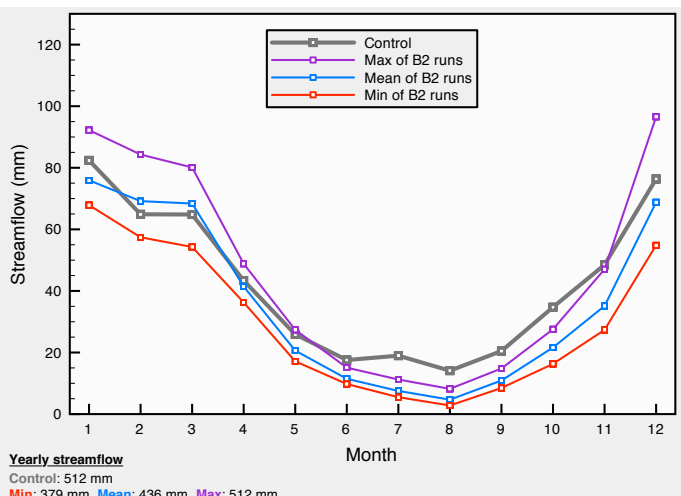

Control: $512 \mathrm{~mm}$

Fig. 7. Mean streamflow from control and climate change (SRES A2 and B2) hydrological simulations - Ourthe at Angleur.

\section{HESSD}

$7,5033-5078,2010$

\section{Climate change and hydrological \\ extremes in Belgian catchments}

P. Baguis et al.

\section{Title Page}

\section{Abstract}

Introduction

Conclusions

References

Tables

Figures

14

- I

$<$

Back

Close

\section{Full Screen / Esc}

Printer-friendly Version

Interactive Discussion 


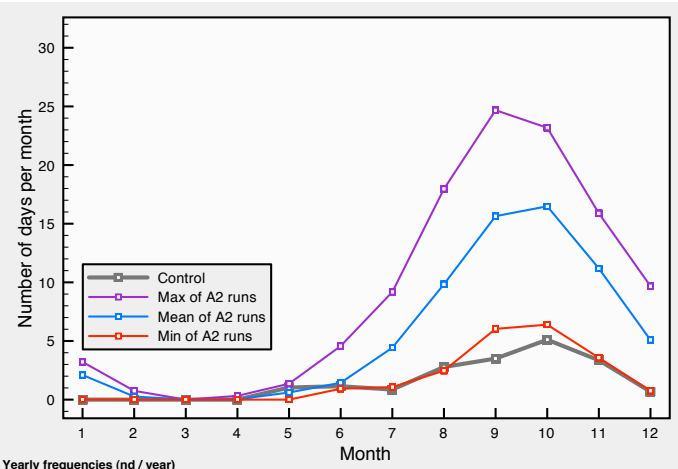

Min: : 2.6. , Mean: 67.1, Max: 99.4

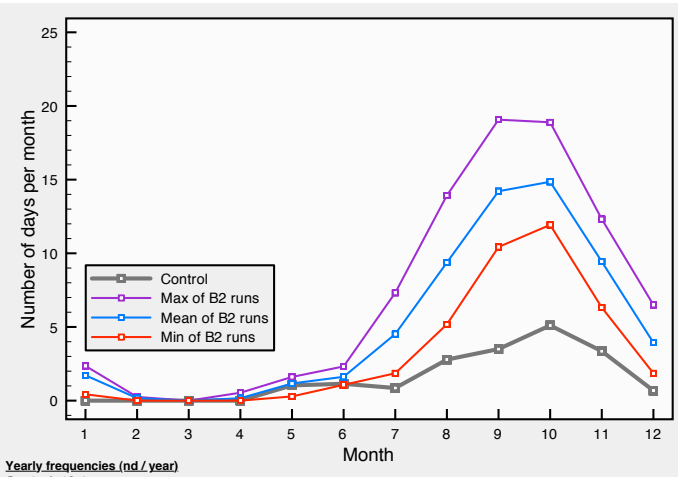

\section{HESSD}

7, 5033-5078, 2010

\section{Climate change and} hydrological

extremes in Belgian catchments

P. Baguis et al.

\section{Title Page}

\section{Abstract}

Introduction

Conclusions

References

Tables

Figures

14

- I

4

Back

Close

\section{Full Screen / Esc}

Printer-friendly Version

Interactive Discussion 


\section{HESSD}

$7,5033-5078,2010$

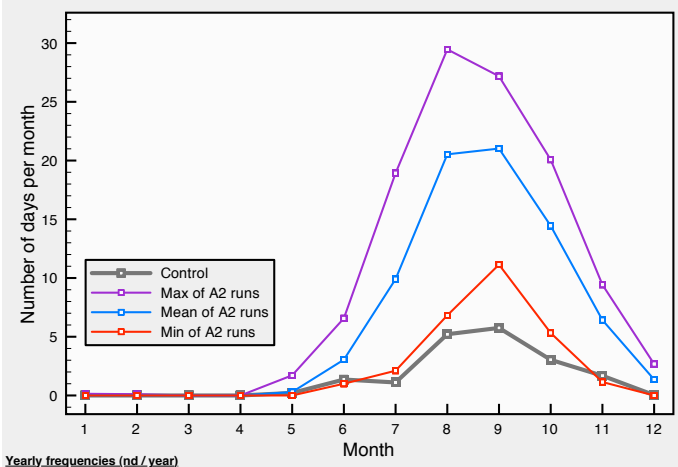

Min: 39.6, Mean: 77.0, Max: 112.4

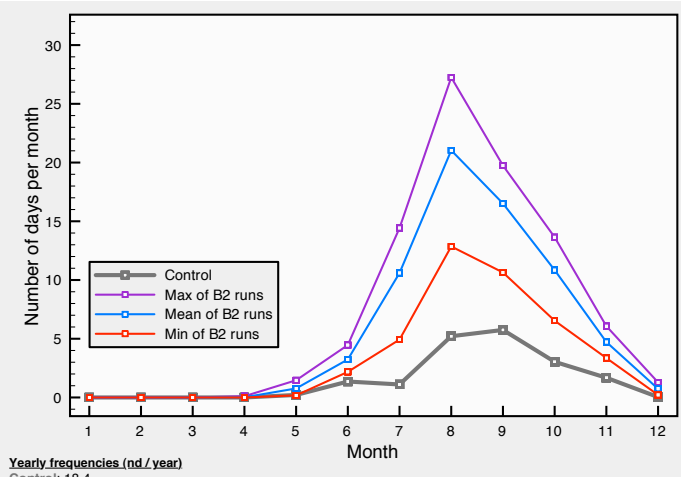

Fig. 9. Low flow frequency ( 0.05 percentile) from control and climate change (SRES A2 and B2) hydrological simulations - Ourthe at Angleur.

\section{Climate change and} hydrological

extremes in Belgian catchments

P. Baguis et al.

\section{Title Page}

\section{Abstract}

Introduction

Conclusions

References

Tables

Figures

14

$\rightarrow$ I

4

Back

Close

Full Screen / Esc

Printer-friendly Version

Interactive Discussion 


\section{HESSD}

7, 5033-5078, 2010

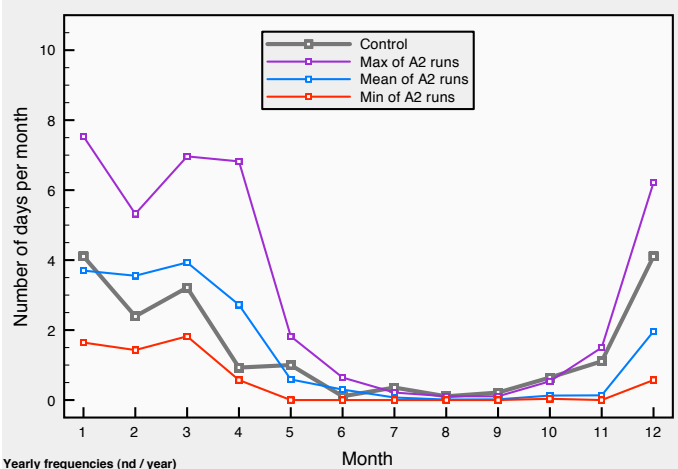

Min: 9.2, Mean: 17.1, Max: 30.1

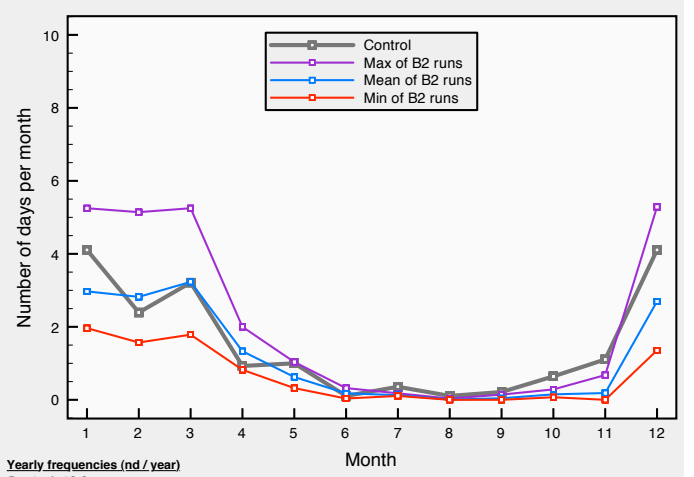

Min: 9.7 , Mean: 14.4, Max: 23.

Fig. 10. High flow frequency ( 0.95 percentile) from control and climate change (SRES A2 and

B2) hydrological simulations - Gete at Halen.

\section{Climate change and hydrological \\ extremes in Belgian catchments \\ P. Baguis et al. \\ Title Page \\ Abstract \\ Introduction \\ Conclusions \\ References \\ Tables \\ Figures \\ 14 \\ $>1$ \\ 4 \\ Back \\ Close \\ Full Screen / Esc}

Printer-friendly Version

Interactive Discussion 


\section{HESSD}

$7,5033-5078,2010$

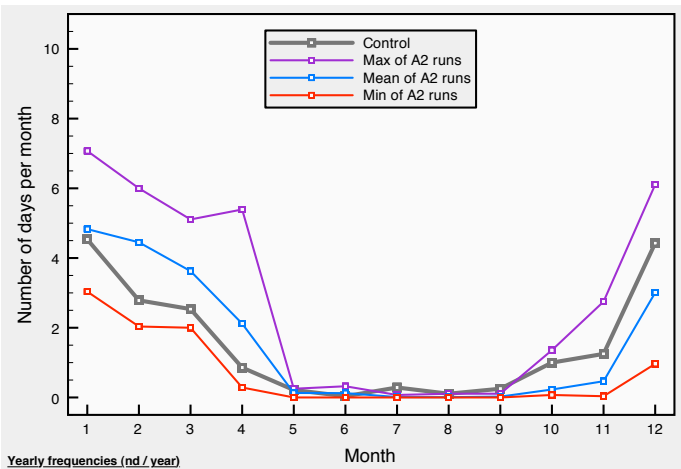

Min: 12.1. Mean: 19.0, Max: 28.1

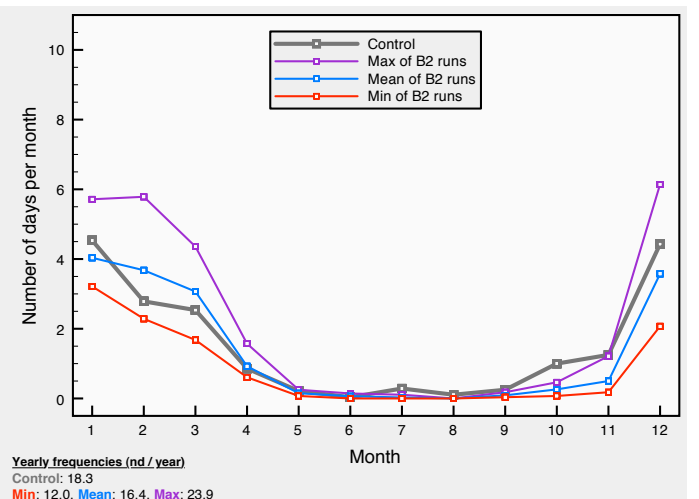

Control: 18.3 .

Fig. 11. High flow frequency ( 0.95 percentile) from control and climate change (SRES A2 and B2) hydrological simulations - Ourthe at Angleur.

\section{Climate change and} hydrological

extremes in Belgian catchments

P. Baguis et al.

\section{Title Page}

\section{Abstract}

Introduction

Conclusions

References

Tables

Figures

14

- I

4

Back

Close

Full Screen / Esc

Printer-friendly Version

Interactive Discussion 


\section{HESSD}

$7,5033-5078,2010$
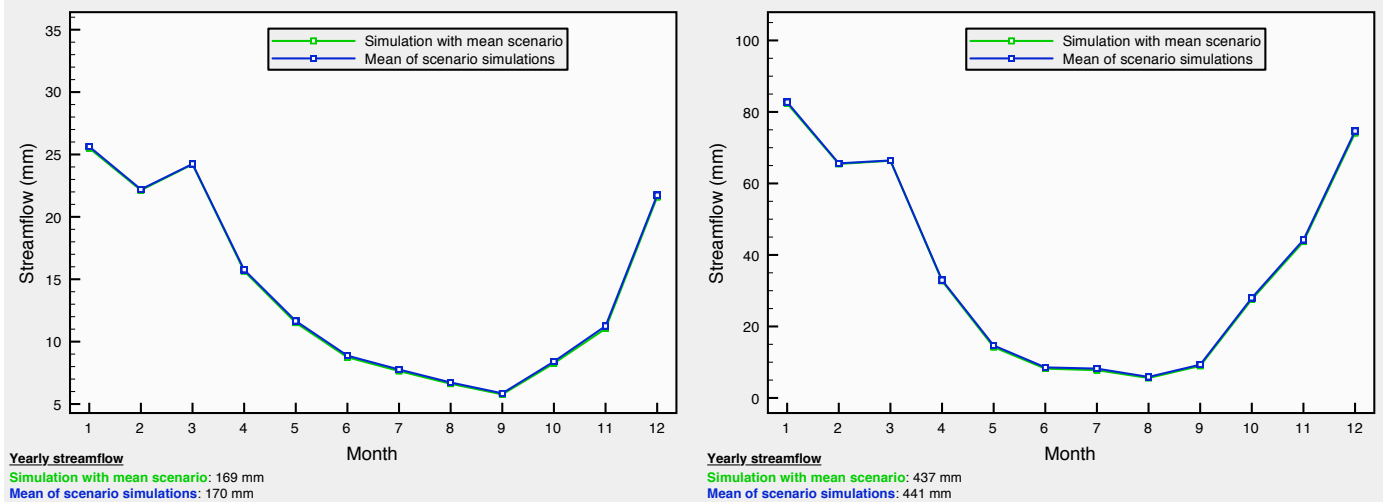

Fig. 12. Mean streamflow for the rivers Gete at Halen (left) and Ourthe at Angleur (right) calculated in two ways: (1) using the mean scenario for precipitation, PET and temperature, where all $A 2$ and B2 simulations have been taken into account, as input in the hydrological model, and (2) using the ensemble of A2 and B2 scenarios for precipitation, PET and temperature as input in the hydrological model and taking the mean in the ensemble of the output hydrological series.

\section{Climate change and hydrological \\ extremes in Belgian catchments}

P. Baguis et al.

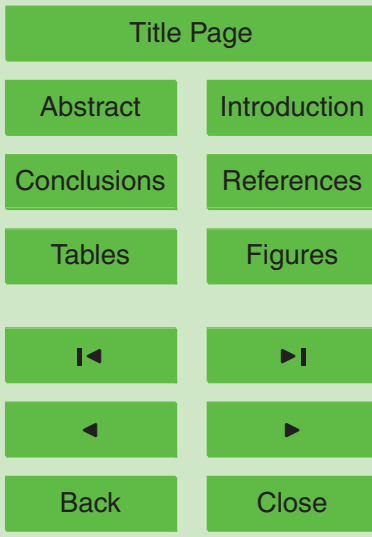

Full Screen / Esc

Printer-friendly Version

Interactive Discussion 